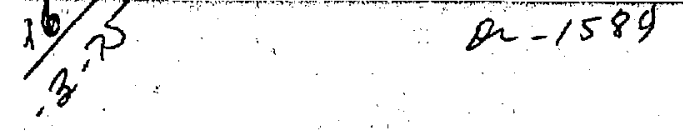

\title{
TRACE ELEMENTS IN CALIFORNIA AEROSOLS PART 1. INSTRUMENTAL NEUTRON ACTIVATION ANALYSIS TECHNIQUES
}

\author{
R. C. Ragaini \\ H. R. Ralston \\ D. Garvis \\ R. Kaifer
}

June 18, 1975

Prepared for U.S. Energy Research \& Development Administration under contract No. W-7405-Eng-4B

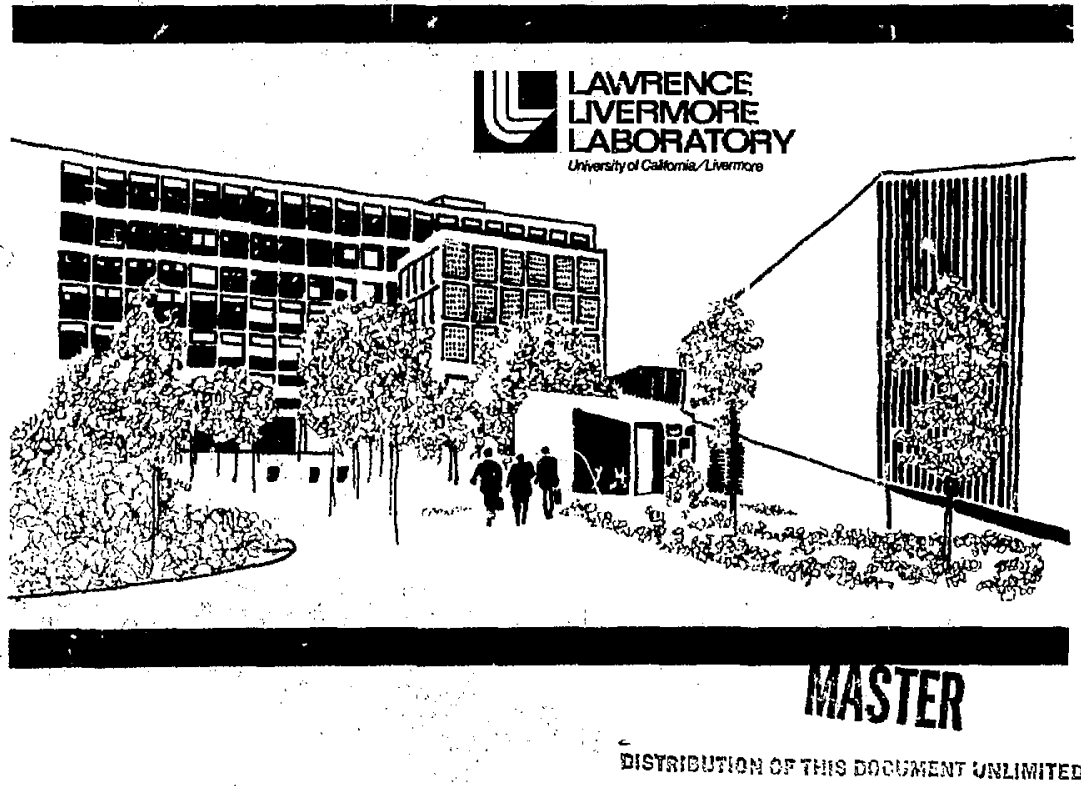


NoTICE

"Thin tepolt whs prepured a in account of work sponered oy the United Stutes Government. Neither the United Starus not the United States Enerty Resarsh \& Develogment Administration, not eny of their enployess, nor any of thetr contractors subcontraston; of thoir employets, makes any wrranty, express or implied, of asumes any lest unblity or responsibility for the cceuracy. complatenes or usefolness of any information, spperatus, product or procts direlowed or spperatus, product or procts disclowed or privately-owned rithts."

\section{Printed in the United States of America Available from \\ National Technical Information Service \\ U.S. Department of Commerce 5285 Port Royal Road Springfield, Virginia 22151}

Price: Printed Copy \$ *; Microfiche $\$ 2.25$

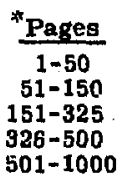

NTIS

Selling Price

$\$ 4.00$

$\$ 5.45$

$\$ 7,60$

$\$ 10.60$

$\$ 13.60$ 
Distribution Category

UC- 1

\title{
노 \\ LAWRENCE LMERMORE LABOFATOAY \\ Unversityol Caltorria Zivemore, Caltomia/94550
}

\author{
UCRL-5i850 \\ TRACE ELEMENTS IN CALIFORNIA AEROSOLS \\ PART I. INSTRUMENTAL NEUTRON ACTIVATION \\ ANALYSIS TECHNIQUES \\ Final Report \\ California Aerosol Characterization Experiment \\ $1972-1974$ \\ R. C. Ragaini \\ H. F, Ralston \\ D. Garvis \\ R. Kaifer
}

MS. date: June 18, 1975

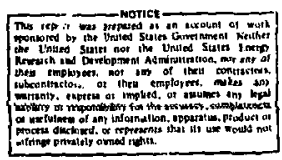




\section{Foreword}

This report will be included in Volume II of the final report, "Characterization of Aerosols in California (ACHEX) Study," submitted to the Air Resources Board of the State of California as Rockwel: International Science Center Report SC524.25FR, September, 1974. This LLL report was prepared for the Air and Industrial Hygiene Laboratory of the California State Department of Public Health under Agreement Number 601 .

Part I consists of a description of the proceriures used for Instrumental Neutron Activation Analysis (INAA), validation tests, analyses of blank, and sample data.

Part Il includes presentations of the episodic data for Phase I and II, the elemental diurnal patterns and size distributions. Analyses of the background site data and the source-enriched site data are used to discuss the sources of the trace elements and the various physical and chemical processes during aerosol transport. Also included are preliminary Lundgren impactor validation studies to evaluate the bounce-off problems with various substrates and to evaluate wall-loss effects.

Some of the data contained in this report has already been discussed in prelininary form in several reports and presentations:

1. R. Ragaini, R. Kaifer, and J. J. Wesnlowski, "A Report on Neutron Activation Analysis in ACHEX-I," Air and Inclustrial Hygicne Laboratory (AIHL) Report No. 130 (Soptember 1972).

2. J. J. Wesolowkl, B. R. Appel, A. E. Alcocer, P. K. Mueller, R. Ragaini, and $R$. Kaifer, "Chemical Measurennents of California Atmospheric Acrosols," AIHL Report No. is4 (October 1973).

3. B. R, Appel, J. J. Wesolowski, A. Alcocer, S. Wall, S, Twiss, R. Giauque, R. Ragaini, and R. Ralston, "Quality Assurance for the Chemistry of the Aerosol Characterization Experiment," AIHI. Report No. 169 (July 1974).

4. J. J. Wesolowski, N. K. Mueller, B. R. Appel, S. Wall, A. E. Alcocer, R. Giauque, T. Novakuv, R. C. Ragaini, and R. Kaifer, "Sampling and Chemical Analysis Results," American Cheinical Society National Meeting, Chicago, August 1973.

5. J. J. Wesrolowski, B. R. Appel, A. E. Alcocer, P. K. Mueller, R. C. Ragaini, and $\mathbf{R}$, Kaifer, "Chemical Measurements of California Atmospheric Acrosols," GAF Gesellscha?t fur Aerolsolforschung Conference, Bad Soden, Germany, October 1973. 6. R, C. Rugalni, R, Katfer, and J. J. Wesolowski, "The Role of Neutron Activation Analysio in the Californla Aerosol Characterization Study," Pacific Conference on Chemlstry and Spectroscopy, San Dlego, November 1973.

7. R. C. Ragainl, "Air Pollution Research Objectlves Using Trace Element Analyses," NSF Workahop on Nuclear Techniques for Environmental Trace Elcment Information Relative to Energy Praduction and Consumption, Tallahassee, Florida, June $24-26,1974$, UCRL-75862. 
8. R. D. Gisuque, Lilly Y. Goda, and R. C. Ragaini, "Chemical Characterizailun of California Aerosols by Elemental Analysis," 167th American Chemical Society Conference on Chemiatry and Speciroscopy, Los Angeles, California, April 1974. 9. B. R. Appel, J. J. Wesolowski, G. M. Hidy, R. D. Giauque, Gand R. C. Ragaini, "The Chemistry of California Atmospheric Aerosols," Pacific Conference on Chemistry and Spectroscopy, San Fraicisco, California, October 1974, LCRL-75B63. 


\section{Contents}

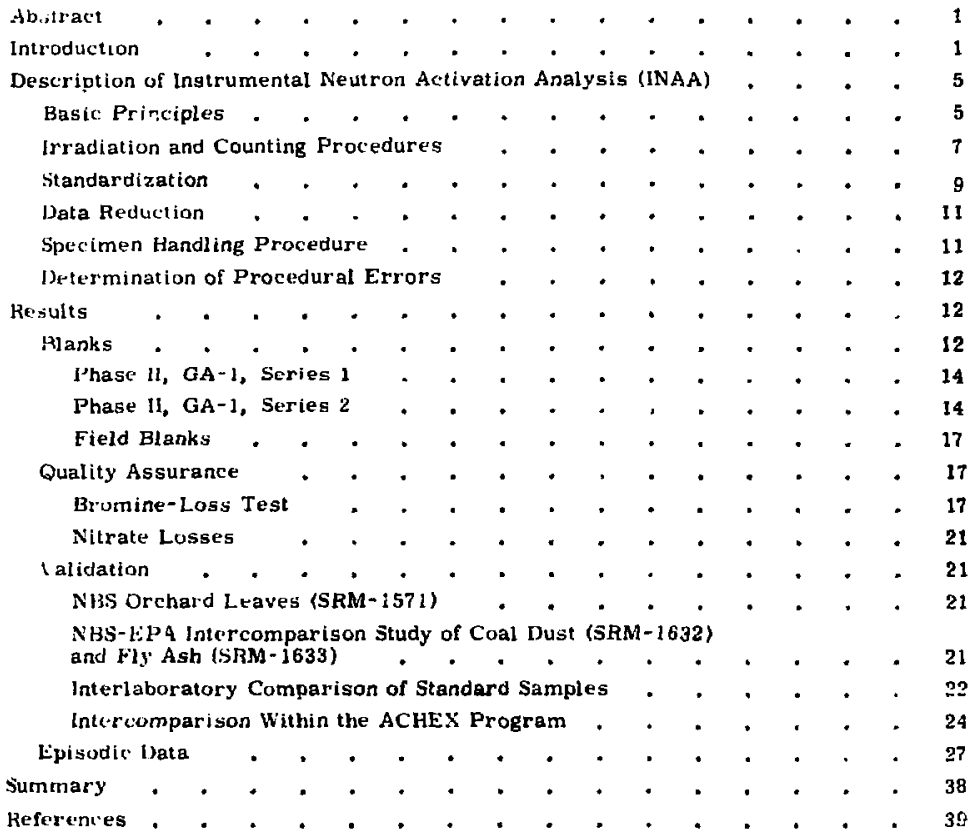




\section{List of Tables}

Table No.

Page No.

1

2

3

4

Propected key chemical constituents of collested particulate matter.

Nicutron-irradiation and sample-counting schedule, . . . 7

Parent, daughter, half-life, and entery of observed gamma rays for elements analyzed by INAA technique in this study.

Detection limits (theoretical) of INAA technique for 75 elements, assuming a l-hr ir radiation with a thermal neutron nux of $10^{13} \mathrm{n} / \mathrm{cm}^{2} / \mathrm{sec}$ and no apprectable interferences. . . . . . . . . 10

Limits of detection for trace elements in aerosols with instrumental neutron activation $\left(\mathrm{ng} / \mathrm{m}^{3}\right)_{*}, . .40$ Grand averages of sample substrate blank determinations. - 13 AIHL Phase II GA-1 lab blanks - first set. . . . . 15 AIHL Phase II GA-I lab blanks - second set. . . . . 16 Fteld blanks - Phase II. . . . . . . . . . 18 Field blank summary - Phase $11 . \quad$. . . . . . . 20 National Burtau of Standards SRM-1571 orchard leaves. . 22 L.L.L resules for NBS/EPA standards zoal and fly ash done by INAA. . . . . . . . . . . . 22

LLL results for NBS/EPA standard coal done by 1NAA. . 23

LLL results for' NBS/EPA standard fly act tone by INAA. . 24 NBS/EPA coal-ny ash comparison. . . . . . . 25 NBS 'EPA coal-fly ash comparison. . . . . . . 26

First XRFA intercomparison study - ratio of $A$ and $C$ averages to gravimetric standards. $0 . \quad$. . . . 27 Comparison of data determined by INAA (LLL) and XAF (LBL). 


\section{List of Figures}

Figure No.

Page No.

1

2

3

4

G

7

B

$(1$

10

11

12

Schematic diagram of instrumental neutron activation analysis procedure.

5

Block diagram of INAA detector system.

Gamma-ray spectrum of Dominguez Hills impactor sample collected on $10 / 5 / 73$ from 2100 to 2100 ,

Stage $1 \mathrm{~A}$.

Gamma-say spectrum of Dominguez Hills impactor sample collected on 10/5/73 from 2100 to 2100 ,

Stage IB.

Gamma-ray apectrum of Dominguez Hills impactor sample collected on $10 \% / 73$ from 2100 to 2100 ,

Stage 4.

Gamma-ray spectrum of Dominguez Hills impactor sample collected on $10 / 5 / 73$ from 1000 to 1200 after

filter.

Gamma-ray spectrum of Dominguez Hills impactor sanple collected on $10 / 5 / 73$ from 1000 to 1200

total rilter.

Particle size distribution of $\mathrm{Br}, \mathrm{Cl}, \mathrm{Na}, \mathrm{Al}$, collected at Harbor Freeway, 9/20/73.

Diurnal patterns of selected elements at Harbor

ireeway, 9/20/73.

biurnal patterus of selected elements at Pasadena, H/24/72.

Diurnal patterns of selected elements at Fresno, $4,1 / 72$.

Diurnal patirrns of selected elements at Pomona, 


\title{
TRACE ELEMENTS IN CALIFORNIA \\ AEROSOLS PART 1. INSTRUMENTAL NEUTRON ACTIVATION ANALYSIS TECHNIQUES
}

\begin{abstract}
Instrumental Neutron Activation

Analysis (INAA) done at LLL played a key role in the 1972-1974 California Acrosol Characterlastion Experiment (ACHEX). a major experiment in the chemistry of aerosols in urbai and non-urban sites of California sporsored by the State of California Air Resources Board. The main purpose of INAA was to measure the particle size distributions and diurnal patterns of key chemical constituents in aerosols collected in California. These data were used to satisfy some of the key objectives of ACHEX, including aeros'ol

characterization and traluation of the origins and evolutions ', armisnls.

Secondary uses of IXAA were the validations of the Lunfgren "stating drum cascade impartirs usint in the Actlix, and validations of ather analytical techniques used in the rhemical analyses.

As a result if these stielie's, it was concluded that : nniques using INAA were useful uperational methods tor chemical analysis of aerosnls whlected roen twohour periuds in urban air with ar active monitoring program.
\end{abstract}

\section{Introduction}

Recognizing that the origins and evolution of atmospheric aerosols were poorly understood, the California Air Resources $B$-ara (AIRB) sponsored a ntajc، experiment $\therefore$ the chemistry of aerosols in urban and non-urban sites of California during 19721974.

The first phase of the study (ACHEX-I) emphasized the gathering of a wide variety of data characterizing atmosphertc aerosols sampled in late summer and fall of 1972. The second phase (ACHEX-II) was primarily concerned with smog aerosols in the South Coast Air Basin during 1973.
The objectives of ACHEX-I were:

- To characterize the aerosols in the South Coast, the San F'twicisco Bay Arca, and the San Joaquin V'alley Basins in terms of their r.ysical and chemical properties, interaction with atmospheric gases, and natural and anthropogenic origins.

- To evaluate the amount of atmospheric aurosol in the cited three major air basins which can be related to: (1) primary emissions such as from auto exinausts or smokestacks; and (2) secondary 
production due to physical and chemical processes taking place in the atmosphere.

- To identify those major sources of particles and chemically reactive gases which can be related to aerosol pollution and visibility reduction.

- To estimate from aerosol source characterization in the three major regions the extent to which the ambient air quality standards can be achieved by existing technology.

- To evaluate the applicability of the aerosol anaiysis instrumentation employed in this study for use in other monitoring networks.

The objectives of ACHEX-II were:

- To characterize aerosols in the South Coast Basin in terms of their physical and chemical properties and their interaction with atmospheric gases.

- To improve knowledge of secondary aerosol formation processes by investigating the evolution of aerosols under conditions of photochemical smog formation.

- To estimate the primary and secondary aerosol contributlons to the total alrborne particulate concentration in the South Coast Basin.

- To evaluate the significance of anthropogenic sources and uncontrollables, including meteorological factors, natural sources, and water, in the evolution of the respirable and visibllity degrading aerosol.

- To recornmend from the characteriration of aerosols and thetr sources the $\therefore y$ Ingrediente for a control strategy in the South Coast Basin.
- To evaluate the applicabijity of instrumentation employed in this study for use in future monitoring programs.

The program was managed by the Science Center Rockwell International; it directly involved the California Air and Industrial Hygiene Laboratory, California Institute of Technology, Meteorology Research Inc., the Statewide Atr Pollution Research Center (SAPRC) of the University of California, Riverside, the University of Minnesota, Thermo-Systems, Inc., Lawrence Berkeley Laboratory, Lawrence Livermore Labor atory, the University of Washington, the ARB El Monte Laboratories, and the Bay Area Air Pollution Control District (BAAPCD).

The ACHEX was designed to achieve its objectives through intensive and detained episodic measurements of aerosol behavior in the presence of trace gases and meteorological changes.

Generally, each run in the field experiment consisted of a 24 -hour period. The operations were selected on the basis of an aerometric forecast one day ahead of startup. The run periods were selected mainly on the basis of conditions conducive to high levels of air pollution. In the South Coast Basin, runs were planned for oxidant levels exceeding $0.20 \mathrm{ppm}$, except for source-dominated cases.

The intensive acquisition of data took place during a two-year period from 1972 to 1973 , with most of the activity concentrated in the late summer and early fall to cover times of highest photochemical smog intensity, as measured by elevater oxidant concentrations. The keystone of the meagurement prograin was a mobile laboratory equipped with a variety of 
instrumentation. The mobile unit was moved to several different sites during the course of the field studies. Sites were selected to provide key information on: (1) source-dominated air, (2) receptor cases where pollutants were mixed and had reacted for a period of time, or (3) non-urban locations potentially characteris tic ol marine, desert, or photochemical background contaminaticn,

Thu mobile laboratory operations were supplemented by fixed stations. In ACHEX-I (1972), these stations were at the Keck laboratories at Caltech, the SAPRC monitoring station at Riverside, and the BAAPCD station in San Jose. During the 1973 phase, the fixed stations were replaced in the South Coast Basin by a modification of four district air-monitoring stations. These included the LAAPCD stations at downtown Los Angeles and Pomona, the ARB station in Riverside, and the OCAPCD station in Anaheim.

A key element of the ACHEx was the extensive chemical analysis undertaken on selected aerosol samples during the course of the experiment. Samples for study were chosen on the basis of priority for the intensity of air pollution observed, or in terms of other information required to meet the objectives of the program.

Many of the chemical methods used in ACHEX required Tevcls of sensitivity that exceded routine procedures in the past. Therefore, considerable development of methorls was undertaken, including neutr on activation analysis (NAA), $x$-ray fluorescence analysis (XRFA), photoelectron spectroscopy (ESCA), highresolution spectroscopy, atomic absorption (AAS), and wet chenical methods for non-carbonate carbon, sulfate, nitrate, and liquid water content. Our group at Lawrence Llvermore Laboratory was responsible for carrying out the INAA measurements.

In the ACFEX, more than 3000 samples of aerosols were collected during 19711973 and INAA was utilized to nondestructively anslyze the particulates on 700 samples including whatman 41 highvolume filters, Gelman 5- $\mu$ GA-1 cellulose-acetate, low-volume total filters and filters after Lundgren rotating drum cascade impactors. Varíous ímpactor films were used and analyzed in the experiment: Mylar, Teflon, sticky-resin-coated polyethylene, and paraffinated Mylar. The only collection media not studied were glass fiber and silver membrane filters.

The normal procedure was to cut out sections of the substrate and perform INAA as well as XRFA for elemental analyses. Although INAA and XRFA are complementary techniques for traceelement analyses because of differing elemental detection sensitivities, a number of elements are measured in both techniques such as $\mathrm{Fe}, \mathrm{Br}, \mathrm{V}, \mathrm{Mn}$, and $\mathrm{Ca}$. Interlab comparisons were made to validate the elemental analyses, and the agreements were quite satisfactory. The comparison did point out the importance of validation in an environmental program, especially when chemical analyses are performed by different methods. The data were transmitted to AIHL on IBM punch cards for computer data hank storage and later analysis.

\footnotetext{
"Reference to a company or product name does not imply approval or recommendation of the product by the University of California or the U. S. Energy Research \& Development Administration to the exclusion of others that may be suitable.
} 
The strategy for determining the sources of the aerosols was based on measurements of the "rey chemical constituents as shown in Table 1. INAA played a signtficant role because of tts abilty to determine a large number of the chemical constituents of interest. Therefore, NAA could detect elements indicative of windblown dust such as $\mathrm{Al}$ and rare earths (not shown), elements indicative of marine aerosols such as $\mathrm{Na}$ and $\mathrm{Cl}$, and elements introduced by man such as $\mathrm{Br}$, $\mathrm{V}, \mathrm{Zn}$, and Se. The elements detected by INAA are marked with an asterisk.

As discussed in more detail later, two irradiations and four different counts were involved in the analyses. The $L L L$ 3-MW Pool-Type Reactor (LPTR) was used for the irradiations. Gamma-ray spectra were taken with a $40-\mathrm{cm}^{3}$

Table 1. Projected key chemical constituents of collected particulate matter.

\begin{tabular}{|c|c|}
\hline Filer.ent or molecular constituent & Remarks and posstble origins \\
\hline C (total and organics) & $\begin{array}{l}\text { Primary-natural and anthropogenic sources } \\
\text { secondary -photochem (?) }\end{array}$ \\
\hline $\begin{array}{l}\mathrm{N} / \mathrm{NO}_{3}^{-}, \mathrm{NH}_{4^{4}}^{+} \text {amino and pyridino } \\
\mathrm{Na}^{\mathrm{a}}\end{array}$ & $\begin{array}{l}\text { Sources - oxidation of } \mathrm{NO}_{x}, \mathrm{NH}_{3} \text {, fuel additives } \\
\text { Malnly sea salt }\end{array}$ \\
\hline $\mathrm{Al}^{\mathrm{a}}$ & Mainly soil - same possible-anthropogenic \\
\hline Sl & Mainly soil \\
\hline $\begin{array}{l}\mathrm{S}\left(\mathrm{SO}_{4}^{-}, \mathrm{SO}_{3}^{-}, \mathrm{S} \cdots\right) \\
\mathrm{C}^{\mathrm{a}} \\
\mathrm{K}^{\mathrm{a}}\end{array}$ & $\begin{array}{l}\text { Mainly secondary production from } \mathrm{SO}_{2} \text { oxidation } \\
\text { Mainly sea salt, but some man made } \\
\text { Malnly natural (?) }\end{array}$ \\
\hline $\mathrm{Ca}^{\mathrm{a}}$ & Cement production \\
\hline $\mathrm{Tl}^{\mathrm{a}}$ & Anthropogenic and natural \\
\hline $\mathrm{v}^{\mathrm{a}}$ & Power plant - fuel oil \\
\hline $\mathrm{Cr}^{\mathrm{a}}$ & Anthropogenic \\
\hline $\mathrm{Mn}^{\mathrm{a}}$ & Ant hropogenic \\
\hline $\mathrm{Fe}^{\mathrm{a}}$ & Anthropogenic and natural \\
\hline N1 & Anthropogenic \\
\hline $\mathrm{Cu}^{\mathrm{a}}$ & Anthropogenic \\
\hline $\mathrm{Zn}^{\mathrm{a}}$ & Tire dust, smelting, fuel additıves \\
\hline $\mathrm{As}^{\mathrm{a}}$ & Combustion, metal prod, and proc. \\
\hline $\mathrm{Se}^{\mathrm{a}}$ & Combustion \\
\hline $\mathrm{Br}^{\mathrm{a}}$ & Auto exhaust \\
\hline $\mathrm{Cd}$ & Metal prod. and proc. \\
\hline $1^{\mathrm{a}}$ & Sea salt and (?) \\
\hline $\mathrm{Ba}^{2}$ & Diesel exhaust and lub oil atomization \\
\hline $\mathbf{P b}$ & Auto exhaugt, industrial proc. \\
\hline $\mathrm{H}_{2} \mathrm{O}$ & $\begin{array}{l}\text { Liquid water content is a potentially important } \\
\text { inert tngredient in visibil ity question }\end{array}$ \\
\hline
\end{tabular}

\footnotetext{
${ }^{a}$ Elements detected by INAA.
} 
lithium-drifted germanium detector, Ge(Li). For a complete irradiation sequence, 20 to 30 elements were reported, For a short irradiation, about 10 elements were routinely detected. The data-transmission time was as short as one day and normally one week for short-irradiation elements, and was about a month for long-irradiation elements.

As a rosult of these studies, new methods cf aerosol analysis using NAA are considered to b' useful operational methods tor samples collected over two-bour periods in urban air.

\section{Description of Instrumental Neutron Activation Analysis (INAA)}

Since its inception, INAA has become increasingly more important as a tool for doing trace-element analysis. This is due to progressive improvements in ts sensitivity made possible by the use of high-resolution, solid-state radiation detictors, improved data-reduction techniques and schemes, and increased experience in smple preparation and collection me hads.

To be most useful, the INAA technique requires a high thermal neutron flux of the type usually found only in a nuclear reactor. Neutron fluxes of $10^{12}$ to $10^{14}$ $\mathrm{n} / \mathrm{cm}^{3} / \mathrm{sec}$ can be easily obtained at most reactor facilities.

\section{BASIC PRINCIPLES}

The procedure used for INAA is to take a sample, expose it to a neutron flux, measure the induced activity as a function of energy, and evaluate the data to quantify the elements present in the original samples (Fig, 1). In practice, the samples contain many elements and occasionally several isotopes of the same element. The activation/counting scheme employed must be chosen in such a manner as to optimize the activity of as many elements is is reasonably possible. This involves making two or more separate irradiations for each sample and applying various counting

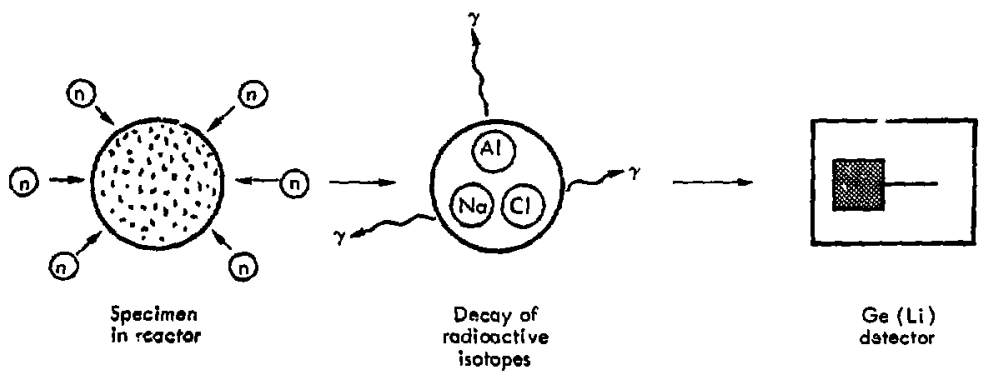

Fig. 1. Schematic diagram of instrumental neutron activation analysis procedure. 
schedules, depending on the type of sample and the elements being sought in the analysis. The irradiation schedule and counting scheme used in this study are discussed in detail below.

The terms Q1 and Q2 refer to the first and second count respectively, after the short irradiation, and L1, L2, L3 likewise refer to the long irradiation.
For this study the neutron source was the Llvermore Pool-Type Reactor (LPTR). The LPTR is a 3-MW thermal research reactor operated for the U.S. Energy Research and Development Administration (ERDA) by the University of California Lawrence Livermore Laboratory.

Figure 2 is a block diagram of the detector system used. It is built around

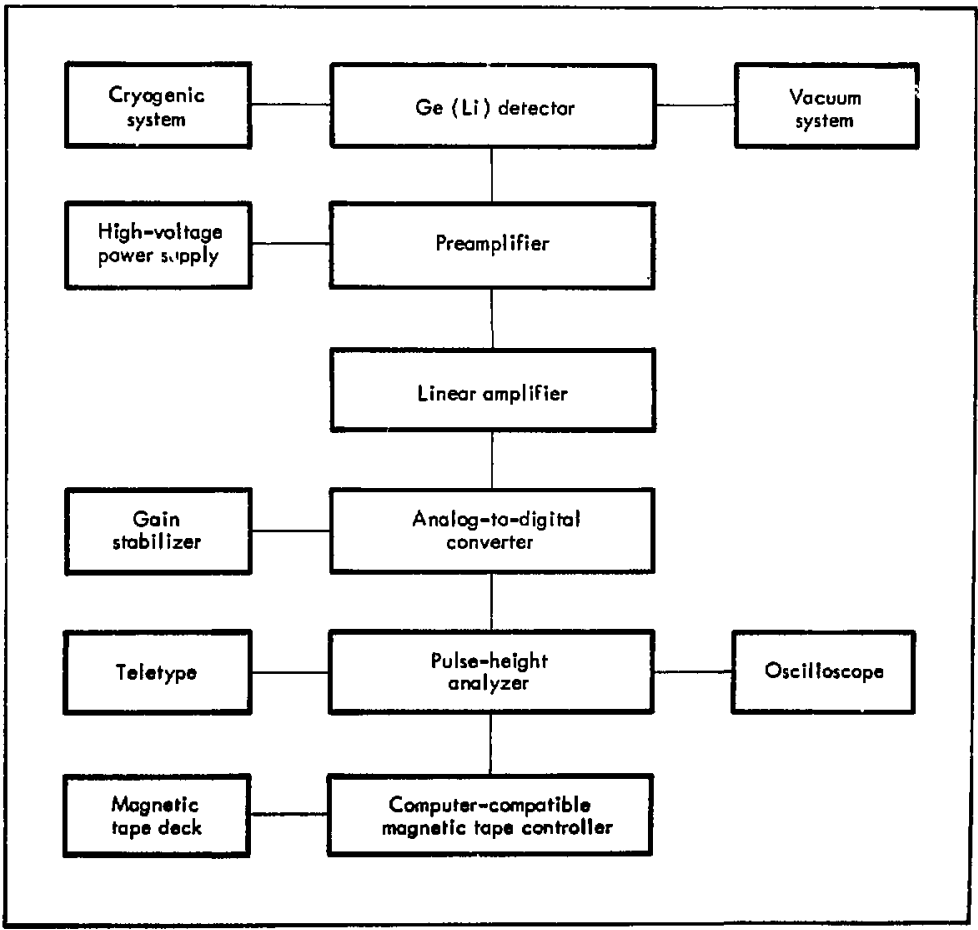

Fig. 2. Block diagram of INAA detector system. 
a $40-\mathrm{cm}^{3} \mathrm{Ge}(\mathrm{Li})$ detector, coupled to 4 4096-ctiannel pulse-height analyzer and the appropriate linear electronics.

\section{IRRADIATION AND COUNTING PROCEDURE}

The irradiation and counting scheme shown in Table 2 was designed to give the maximum sensitivity for the wide range of elements. The scheme is similar to that used by othres for the same type of analyses, $1-3$

The data derived were recorded on computer-compatible magnetic tape for permanent reference and for subsequent reduction and analysis. The procedure is effective for the identification of approximately 35 elements in a single sample.

Table 3 gives a listing of the parent nuclide, half-life, daughter product, and energy of the gamma rays used in the analysis of the elements of interest.
Table 3 shows that ${ }^{65} \mathrm{Zn}$ has a gamma ray with an energy of $1115.4 \mathrm{keV}$. Thus, if there are large amounts of both $\mathrm{Zn}$ and Sc in a sample, it may not be possible to separate the gamma-ray peaks since they would overlap when detectors with currently available resolutions are used. Scandium has another gamma ray with an energy of 689.4 keV, and the only appreciable interference with this peak is the $110 \mathrm{~m} \mathrm{Ag}$ gamma ray at $884.7 \mathrm{keV}$, By the use of curve-fitting techniques and spectrum stripping, it is possible to resolve large amounts of ${ }^{110 \mathrm{~m}} \mathrm{Ag},{ }^{46} \mathrm{Sc}$, and ${ }^{65} \mathrm{Zn}$ in the same sample. A close examination of Table 3 reveals several other interferences of the type discussed above which occur in a typical sample. The detection limits for 75 elements are given in Table 4 , based on a maximum irradiation time of onte hour, a thermal neutron fux of $10^{13} \mathrm{n} / \mathrm{cm}^{2} / \mathrm{sec}$, and no appreciable interferences. ${ }^{4}$ These detection limits can,

Table 2. Neutron-irradiation and sample-counting schedule.

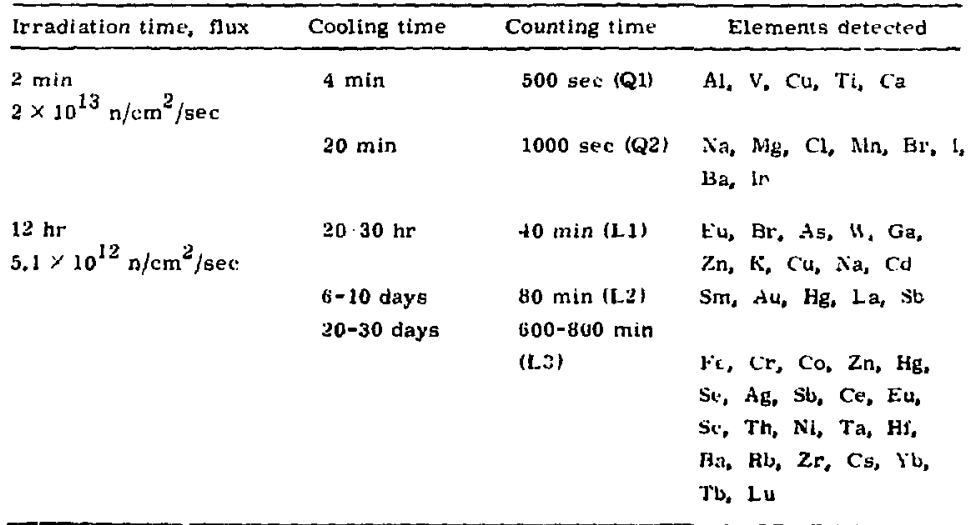


Takle 3. Firent, daughter, half-life, and energy of observed gamma rays for elements analyzed by INAA technique in this study.

\begin{tabular}{|c|c|c|c|c|}
\hline $\begin{array}{l}\text { Parent } \\
\text { element } \\
\text { exposed }\end{array}$ & $\begin{array}{l}\text { Daughter } \\
\text { Isotope } \\
\text { observed }\end{array}$ & \multicolumn{2}{|c|}{ Half-life ${ }^{a}$} & Gamma-ray energy observed ${ }^{b}$ \\
\hline $\mathrm{Ti}$ & ${ }_{22}^{51} \mathrm{Ti}$ & \multicolumn{2}{|c|}{$5.79 \mathrm{~m}$} & $320.0(100)$ \\
\hline $\mathrm{Mg}$ & ${ }_{12}^{27} \mathrm{Mg}$ & \multicolumn{2}{|c|}{$9.46 \mathrm{~m}$} & $843.8(100), 1014.5(37.5)$ \\
\hline $\mathrm{Cu}$ & ${ }_{29}^{66} \mathrm{Cu}$ & \multicolumn{2}{|c|}{$5.10 \mathrm{~m}$} & $1039.2(100)$ \\
\hline V & $\begin{array}{l}52 \\
23\end{array}$ & \multicolumn{2}{|c|}{$3.75 \mathrm{~m}$} & $1434,3(100)$ \\
\hline Al & ${ }_{13}^{28} \mathrm{AI}$ & \multicolumn{2}{|c|}{$2,52 \mathrm{~m}$} & $1778.7(100)$ \\
\hline $\mathrm{Ca}$ & ${ }_{20}^{49} \mathrm{Ca}$ & \multicolumn{2}{|c|}{$8.80 \mathrm{~m}$} & $3084.4(100)$ \\
\hline $\mathrm{Ba}$ & ${ }_{56}^{139} \mathrm{Ba}$ & 82.9 & $\mathrm{~m}$ & $165.8(100$ \\
\hline I & ${ }_{53}^{128} 1$ & 25.0 & $m$ & $443.3(100), 526.4(9.9)$ \\
\hline $\mathrm{Br}$ & ${ }_{35}^{80} \mathrm{Br}$ & 16.8 & $\mathfrak{m}$ & $616.2(100), 665.6(17.2)$ \\
\hline In & ${ }_{49}^{116} \ln$ & 53.7 & $\mathbf{m}$ & $417.0(40.2), 1097.1(59.8), 1293.4(100)$ \\
\hline $\mathrm{Na}$ & ${ }_{11}^{24} \mathrm{Na}$ & 15,0 & $\mathbf{h}$ & $1368.4(100), 2754.1(100)$ \\
\hline $\mathrm{Cl}$ & ${ }_{17}^{38} \mathrm{Cl}$ & 37.3 & $\mathrm{~m}$ & $1642.7(74.5), 2167.6(100)$ \\
\hline $\mathbf{M n}$ & $\begin{array}{l}56 \\
25\end{array}$ & 155.0 & $\mathrm{~m}$ & $846.7(100), 1811.2(29.4)$ \\
\hline As & ${ }_{33}^{76} \mathrm{As}$ & 26.4 & h & $559.1(100), 657.1(100)$ \\
\hline W & ${ }_{74}^{187} \mathrm{~W}$ & 23.9 & $\mathbf{h}$ & $134.2(31.6), 479.5(83.1), 618.2(23.1), 685.7(100)$ \\
\hline Ga & ${ }_{31}^{72} \mathrm{Ga}$ & 14.1 & $\mathbf{h}$ & $629.9(25.5), 834,0(100), 2201.6(27.3)$ \\
\hline $\mathbf{K}$ & ${ }_{10}^{42} \mathrm{~K}$ & 12.4 & $\mathbf{h}$ & $1524.7(100)$ \\
\hline Cd & ${ }_{48}^{115} \mathrm{Cd}$ & 53.5 & $\boldsymbol{h}$ & $452.3(29.5), 527,9(100)$ \\
\hline $\mathrm{Sm}$ & ${ }_{62}^{133} \mathrm{Sm}$ & 48.8 & $h$ & $103,2(100)$ \\
\hline Au & If ? & 64.7 & $\mathbf{h}$ & $411.8(100)$ \\
\hline La & ${ }_{57}^{+1 U} L_{a}$ & 40.2 & h & $328,8(21.4), 487.0(49,4), 1596,6(100)$ \\
\hline $\mathbf{F e}$ & ${ }_{26}^{59} \mathrm{Fe}$ & 45,6 & d & $1099.3(100), 1291.5(77,0)$ \\
\hline
\end{tabular}


Table 3. (continued)

\begin{tabular}{|c|c|c|c|c|}
\hline $\begin{array}{l}\text { Parent } \\
\text { element } \\
\text { exposed }\end{array}$ & $\begin{array}{l}\text { Daughier } \\
\text { isotope } \\
\text { observed }\end{array}$ & \multicolumn{2}{|c|}{ Hlalf-life ${ }^{a}$} & Gamma-ray enu rgy observed ${ }^{b}$ \\
\hline $\mathrm{Cr}$ & ${ }_{24}^{51} \mathrm{Cr}$ & 27.8 & d & $320.1(100)$ \\
\hline Co & ${ }_{27}^{60} \mathrm{Co}$ & 5.26 & $y$ & $1173.2(100), 1332.5(200)$ \\
\hline Zn & ${ }_{30}^{65} \mathrm{Zn}$ & 24.3 & d & $1: 15,5(100)$ \\
\hline $\mathbf{H g}_{\mathbf{g}}$ & ${ }_{80}^{203} \mathrm{Hg}$ & 46.9 & d & $278.2(100)$ \\
\hline Se & ${ }_{34}^{75} \mathrm{Sc}$ & 120 & d & $136.0(86.0), 264.7(100)$ \\
\hline $\mathbf{A g}$ & ${ }_{47}^{i n g m} \mathrm{Ag}$ & 5.00 & $d$ & $434.0(100), 614.4\{100\}, 723.0(100)$ \\
\hline Ag & ${ }_{47}^{\mathrm{IIO}} \mathrm{Ag}$ & 25,5 & $d$ & $657,7(100), 884.7(79,6), 937,5(36,5), 1384.2(27.7)$ \\
\hline $\mathrm{Sb}$ & ${ }_{51}^{124} \mathrm{Sb}$ & 60.3 & d & $602.7(100), 1692.1(53.2)$ \\
\hline $\mathrm{Cc}$ & ${ }_{58}^{141} \mathrm{Cc}$ & 32,5 & d & $145.5(100)$ \\
\hline Eu & ${ }_{63}^{152} \mathrm{Eu}$ & 12.7 & $\mathbf{y}$ & $121.8(100 ; 344,2(85,5), 1+08.1(65.0)$ \\
\hline Sc & ${ }_{21}^{46} \mathrm{Se}$ & 83.9 & d & $889.3(100), 1120.5(100)$ \\
\hline Th & ${ }_{91}^{\angle 33} \mathrm{~Pa}$ & 27.0 & d & $311.9(100)$ \\
\hline $\mathrm{Ni}$ & ${ }_{27}^{58} \mathrm{Co}$ & 71,3 & d & $811.1(100)$ \\
\hline HS & ${ }_{72}^{175} \mathrm{Hf}$ & 70.0 & d & $343.4(100)$ \\
\hline Hí & ${ }_{72}^{181} \mathrm{Hf}$ & 42.5 & d & $133.1(49.4), 482.2(100)$ \\
\hline
\end{tabular}

Ti.ne unitg are as follows: $m=$ minutes, $h=$ hours, $d=$ days, $y=y e$ ars.

b Numbers given in parentheses following the gamma-ray cnurgs are the relatuve intensities (\%) of the gamma rays.

therefore, be thought of as theoretical limits within the state of the art. Detection limits are shown in Table 5 for the twohour samples analyzed in the ACHEX study.

\section{STANDARDIZATION}

In order to generate accurate quantitative information, neutron activation analysis (NAA) must mike accurato cump.ti = sons of the sample clemental counting Information with that for the elemental standard. The elemental standards are individually prepared by dissolving a known amount of the element of intrest as a high-purity metal, oxide or assayed compound, as the chemistry dictates, into triple-quartz-distilled water or 
dilute quartz-distilled acid. Ailquots of these atandards are then spctted onto blank fllters of Whatman 41 or Geiman Ga-1, and the fllters are processed through the routine NAA procedure describud abovi. These experiments basically provide values of the conversion factor of nanograms per count for each

Table 4. Detection linits (theoretical) of INAA technique for 75 elements, assuming a $1-h$ irradiation with a thermal neutron flux of $1013 \mathrm{n} / \mathrm{cm}^{2}$ /oec and no apprieciable interferences.

\begin{tabular}{|c|c|}
\hline $\begin{array}{l}\text { Limit of detection } \\
(\mu \mathrm{g})\end{array}$ & Elements \\
\hline $1-3 \times 10^{-7}$ & Dy \\
\hline $4-9 \times 10^{-7}$ & Eu \\
\hline $1-3 \times 10^{-6}$ & - \\
\hline $4-9 \times 10^{-6}$ & Mn, In, Lu \\
\hline $1-3 \times 10^{-5}$ & Co, Rh, Ir \\
\hline $4-9 \times 10^{-5}$ & Br, Sin, Ho, Re, AL \\
\hline $1-3 \times 10^{-4}$ & $\begin{array}{l}\mathrm{Ar}, \mathrm{V}, \mathrm{Cu}, \mathrm{Ga}, \underset{\mathrm{As}}{\mathrm{Pd}, \mathrm{Ag}, 1, \mathrm{Pr}, \mathrm{W}}\end{array}$ \\
\hline $4-9 \times 10^{-4}$ & $\begin{array}{l}\mathrm{Na}, \mathrm{Ge}, \mathrm{Sr}, \mathrm{Nb}, \mathrm{Sb}, \\
\mathrm{Cs}, \mathrm{La}, \mathrm{Er}, \mathrm{Yb},{ }^{\mathrm{j}}\end{array}$ \\
\hline $1-3 \times 10^{-3}$ & $\begin{array}{l}\mathrm{Al}, \mathrm{Cl}, \mathrm{K}, \mathrm{Sc}, \mathrm{Se} \\
\mathrm{Kr}, \mathrm{Y}, \mathrm{Ru}, \mathrm{Gd}, \mathrm{T} m, \\
\mathrm{Hg}\end{array}$ \\
\hline $4-9 \times 10^{-3}$ & $\begin{array}{l}\text { St, Ni, Rb, Cd, Te, } \\
\text { Ba, Tb, Hi, Ta, Os, } \\
\text { Pl, Th }\end{array}$ \\
\hline $1-3 \times 10^{-2}$ & $\begin{array}{l}\text { P. Tl, Zn, Mo, sn, } \\
\mathrm{Xe}, \mathrm{Ce}, \mathrm{No}\end{array}$ \\
\hline $4-9 \times 10^{-2}$ & Mg, Ca, T, Bi \\
\hline $1-3 \times 10^{-1}$ & P. C'r, zur \\
\hline $4-0 \times 10^{-1}$ & Ne \\
\hline $1-3$ & $\mathbf{S}, P_{b}$ \\
\hline $1-8$ & $\mathrm{Fe}$ \\
\hline
\end{tabular}

Table 5. Limits if detection ${ }^{a}$ for trace clements in aerosuis with instrup?'ntal neutron activation (ng ${ }^{\prime} \mathrm{m}^{3}$ ).

\begin{tabular}{ccc}
\hline Elcment & $\begin{array}{c}\text { Gelman } \\
\text { GA-1 }\end{array}$ & $\begin{array}{c}\text { Impactor } \\
\text { fi! mb }\end{array}$ \\
\hline $\mathrm{Na}$ & 300 & 200 \\
$\mathrm{Mg}$ & 100 & 10 \\
$\mathrm{Al}$ & 0.3 & 100 \\
$\mathrm{Cl}$ & 1 & 1 \\
$\mathrm{Ca}$ & 1 & 10 \\
$\mathrm{Ti}$ & 10 & 1 \\
$\mathrm{~V}$ & & 0.1 \\
$\mathrm{Mn}$ & 0.6 & \\
$\mathrm{Cu}$ & 0.1 & 1 \\
$\mathrm{Br}$ & & 0.0003 \\
$\mathrm{In}$ & 0.002 & 0.0004 \\
$\mathrm{I}$ & & .02 \\
$\mathrm{Ba}$ & 2 & 0.5 \\
\hline
\end{tabular}

\footnotetext{
above blank.

b Average results for $0.0000-\mathrm{cm}$ Mylar, $0.0025-\mathrm{cm}$ Teflon, and $0.0025-\mathrm{cm}$ poly ethylene covered with $0.004-\mathrm{cm}$ sticky resin.
}

element which is then applied to the sample count data by a computer code to calculate the elemental weights on the filters and Impactor surfacea.

The standardization methods differ for short and long irradiations. The main simllarity in the two methods is that both are pre-mixed solutions containing only those elements of interest. Both have the shortcoinirg of having to prepare standards of approximately the same concentrations ag the samples nf intereat. This necessitates an estimation of the composition of the sample. Th!s estimatinn is critical if one is looking at samples which cruntain large: amounts of elernenta that have interferring gamma rays wuch as silver, scandium and $x$ inc, as described nbove, and if any 
of the short-lived isotopes (eq. . Al, V, (i) vastly predominate during the $Q 1$ count.

For short í radiations, all samples are normalized to a "standard flux monitor." Several dirferent types of flux monitors have been used by different investigators depending an their specific applications, but each was designed to do the same thing, namely, to normalize a given irradiation back to some known condition or parameter. For this study, a titanium nux monitor was used and counted for 60 seconds between the $Q 1$ and Q2 counts, Sever: 1 titanium flux monitors were in use, and all were run for a predetermined tims and counted and found to be statistically identical. The flux monitors were placed in the same position with respect to the sample in the sample carrier during each irradiation. The counts from the flux standard were then ralioed to the master standard count taken with the same flux monitor, ar, all clemontal counts were then ratioed up or down by thi same factor. The ratioing was periormed by the data reduction program, and the program "rlags" any standard ratio that deviates from the master standard by more than $10 \%$.

For the long irradiations, a standard was prepared for each irradiation. The standard was then irradiated with and counted in the same position and sequence as the sample. Any flux variation that existed from one irradlation to another was thereby taken into account. This procedure effectively calibrated and detector for each sample mun.

\section{DAT^ REDUCTION}

The data reduction for the INAA portion of this study was performed using the gamma-ray analysis program MIKEGAM. This program is an adapted version of a technique developed by Ralston and Wilcox. ${ }^{5}$ The accuracy of the code has been verified by use of interlaboratory and intralaboratory comparison studies, which are ciscussed below.

Basically, the code operates by gencrating a baseline from the $G e(L i)$ spectrum. and from this baseline defining and quantitating significant peaks. The program has two major branches; one for processing short irradiation samples, and the other for processing long irradiation samples. The errors contributed by counting statistics, sampling, blank contribution and standards determination are carried along and combined in the final calculations.

\section{SPECIMEN HANDLING PROCELURE}

Our procedures were planned for the following types of samples: GA-1 filters, 0.25- by 1-inch strips of Mylar, and 1-in.-diam Whatman $41 \mathrm{Hi}-$ Vols, sticky film, and paraffinated Mylar. All samples were handled with blunt-ended stainless steel tweezers and inserted into 2-dram polyethylene vials which had been previously cleaned. A vial was then loaded into a reactor polyethylene pneumatic tube "rabbit" along with a titanium foil flux manitor (encased in polyethylene) and a polystyrene disc which acted as a shock absorber. After Irradiation, the sample was removed from the inner vial after the outer "rabbit" had been discarded and the sample was inserted into a clean cellophane bag using clean stainless steel tweezers. The bag-encased sample was then inserted into a Lucite sample holder and placed in 
front of a Ge(Li) detectcr for gamma-ray counting (re. counts $Q 1$ and $Q 2$ ). For samples undergoing the !ng irradiation procedure, a decay period of at least three days was allowed before the long irradiation to allow any radioactivities generated in the short irradiation to die away. For the long irradiation, approximately 12 samples were individually bagged in clean polyethylere, and along with bagged elemental standards, were loaded into a polyethylene capsule which rotated during the 12-hour irradiation to insure flux hoinogeneity. After the irradiation, the samples were run through the L1, L2, and L3 counts. Particular care was taken not to introduce any contaminants in the samples during the short irradiation and suksequent analysis so that the long irradiation analysis would not be affected.

\section{DETERMINATION OF PROCEDIIRAL ERRORS}

To determine the overall error contributed by various procedures such as weighing and pipetting, and ulso the geometry in the reactor irradiation facility and the gamma spectrometer, six sodium standards were prepared in the usual manner, irradiated together, and then counted sequentially. The overall variation in obtained activity from each sodium standard showed a fractional standard deviation of less than $1 \%$.

\section{Results}

\section{BLANKS}

The assignment of average trace quantities in the filter substrate (blank) ranked high among the various factors that had ar effect on the precision of trace element analysis by INAA of air particulate matter collected on filter media. This was especially true when a trace element in the blank was determined with a high degree of uncertainty and the concentration of the depoeited trace element approached that contained in the blank.

For Phage I, various particle collection media were studied. Inttially, the effort was directed toward the evaluation of candidate substrates and after itnal selection to a more detailed characterization of those chosen. The major candidates were Gelman (GA-1), Millipore, a sticky-ourface polyethylene fllm, Mylar, Teflon film, and paraffinated Mylar, An additional variable was the pre-treatment of the mudia which consisted of washing either by the factory or by AIHL.

Phase II sample collection was restricted to the use of GA-1 filters for the total and after filters, sticky polyethylene film for the Lundgren impactor surfaces, and $W-41$ for the high-volume samples. Phase 1 blank values for $\mathrm{W}^{\prime}-41$ and sticky polyethylene were used, but since a new washing procedure was used on Phase II GA-I filters, a separate study was done for them.

Table 6 shows the trace element values In nanograms per square centimeter for each of the substrates used in Phases I and II. The values shown are the grand averages of a varying number of samples of each substrate. They, along with the associated probable errors shown in parentheses, are the best determination of a single value 
Table 6. Grand averages of sample substrate blank determinations $\left(\mathrm{ng} / \mathrm{cm}^{2}\right.$ ).

\begin{tabular}{|c|c|c|c|c|c|c|c|}
\hline & $\begin{array}{c}\text { Phage II } \\
\text { GA-1 }\end{array}$ & $\begin{array}{c}\text { Phase I } \\
\text { GA-1 }\end{array}$ & Mylar & Teflon & $\begin{array}{l}\text { Sticky } \\
\text { film }\end{array}$ & $\begin{array}{l}\text { Faratin } \\
\text { mylar }\end{array}$ & $w-41$ \\
\hline $\mathrm{Na}$ & $\begin{array}{l}53 \\
(0.50)\end{array}$ & $\begin{array}{l}88.8 \\
(0.2)\end{array}$ & $\begin{array}{c}2.8 \\
(0.2)\end{array}$ & $\begin{array}{c}1.5 \\
(0.2)\end{array}$ & $\begin{array}{l}206 \\
10.08)\end{array}$ & $\begin{array}{l}25.01 \\
(0.08)\end{array}$ & $\begin{array}{l}94.2 \\
(0.17)\end{array}$ \\
\hline Mg & $\begin{array}{l}92 \\
(0.24\rangle\end{array}$ & ND & ND & ND & $\mathrm{ND}$ & ND & ND \\
\hline Al & $\begin{array}{l}41 \\
(0.45)\end{array}$ & $\begin{array}{l}29.6 \\
(0.2)\end{array}$ & $\begin{array}{c}4.0 \\
(0.2)\end{array}$ & $\begin{array}{c}4.45 \\
60.3\end{array}$ & $\begin{array}{l}17.5 \\
(0.43)\end{array}$ & $\begin{array}{l}67.4 \\
(0.04)\end{array}$ & $\begin{array}{l}21.5 \\
(0,20)\end{array}$ \\
\hline $\mathrm{Cl}$ & $\begin{array}{l}158 \\
0.21\end{array}$ & $\begin{array}{r}178 \\
0.2\end{array}$ & $\begin{array}{l}6.8 \\
0.2\end{array}$ & $\begin{array}{l}2.6 \\
0.2\end{array}$ & $\begin{array}{c}86.4 \\
0.14\end{array}$ & $\begin{array}{c}34.5 \\
0.12\end{array}$ & $\begin{array}{l}407 \\
0.20\end{array}$ \\
\hline $\mathrm{Ca}$ & $\begin{array}{l}176 \\
(0.41)\end{array}$ & $\begin{array}{l}158 \\
(0.2)\end{array}$ & $\begin{array}{l}\text { ND } \\
0\end{array}$ & $\begin{array}{l}\text { ND } \\
0\end{array}$ & $\begin{array}{l}285 \\
(0.30)\end{array}$ & $\begin{array}{l}57.7 \\
(0.83)\end{array}$ & $\begin{array}{l}70 \\
(0.20)\end{array}$ \\
\hline Sc & $\begin{array}{l}0 \\
3\end{array}$ & $\begin{array}{l}\text { ND } \\
\text { ND }\end{array}$ & $\begin{array}{l}\text { ND } \\
\text { ND }\end{array}$ & $\begin{array}{l}\text { ND } \\
\text { XD }\end{array}$ & $\begin{array}{l}\text { ND } \\
\text { ND }\end{array}$ & $\begin{array}{l}0 \\
0\end{array}$ & $\begin{array}{c}0.01 \\
(0.12)\end{array}$ \\
\hline $\mathrm{Ti}$ & $\begin{array}{l}\text { ND } \\
\text { ND }\end{array}$ & $\begin{array}{l}\text { ND } \\
\text { ND }\end{array}$ & $\begin{array}{l}\text { ND } \\
\text { ND }\end{array}$ & $\begin{array}{c}3.30 \\
(0.20)\end{array}$ & $\begin{array}{c}3.82 \\
(0.52)\end{array}$ & $\begin{array}{c}5.89 \\
(0.52)\end{array}$ & $\begin{array}{l}\text { ND } \\
\text { ND }\end{array}$ \\
\hline V & $\begin{array}{l}\text { ND } \\
\text { ND }\end{array}$ & $\begin{array}{l}\text { ND } \\
\text { ND }\end{array}$ & $\begin{array}{l}\text { ND } \\
\text { ND }\end{array}$ & $\begin{array}{r}0.016 \\
(0.20)\end{array}$ & $\begin{array}{c}0.0272 \\
(0.29)\end{array}$ & $\begin{array}{r}0.112 \\
10.261\end{array}$ & $\begin{array}{l}\mathrm{ND} \\
\mathrm{ND}\end{array}$ \\
\hline $\mathrm{Cr}$ & $\begin{array}{c}0.99 \\
(0.11)\end{array}$ & $\begin{array}{l}8.0 \\
(0.28)\end{array}$ & $\begin{array}{l}0 \\
0\end{array}$ & $\begin{array}{c}1.85 \\
(0.03)\end{array}$ & $\begin{array}{c}0.55 \\
(0.12)\end{array}$ & $\begin{array}{l}0 \\
0\end{array}$ & $\begin{array}{c}1.46 \\
(0.04)\end{array}$ \\
\hline$M n$ & $\begin{array}{l}0.82 \\
0.74\end{array}$ & $\begin{array}{l}0.53 \\
0.2\end{array}$ & $\begin{array}{l}0.03 \\
0.2\end{array}$ & $\begin{array}{l}0.44 \\
0.2\end{array}$ & $\begin{array}{l}0.443 \\
0.53\end{array}$ & $\begin{array}{l}0.722 \\
0.28\end{array}$ & $\begin{array}{l}0.42 \\
0.20\end{array}$ \\
\hline the & $\begin{array}{l}29.4 \\
(0.27)\end{array}$ & $\begin{array}{l}56 \\
(0.3)\end{array}$ & $\begin{array}{l}\text { ND } \\
0\end{array}$ & $\begin{array}{l}11 \\
(0.44)\end{array}$ & $\begin{array}{l}80 \\
(0.08)\end{array}$ & $\begin{array}{l}\text { ND } \\
\text { ND }\end{array}$ & $\begin{array}{l}25.8 \\
(10.09)\end{array}$ \\
\hline $\mathrm{Co}$ & $\begin{array}{l}N D \\
N D\end{array}$ & $\begin{array}{l}\text { ND } \\
X D\end{array}$ & $\begin{array}{l}\text { ND } \\
\text { ND }\end{array}$ & $\begin{array}{c}2.26 \\
(0.03)\end{array}$ & $\begin{array}{l}\text { ND } \\
\text { MD }\end{array}$ & $\begin{array}{l}\mathrm{ND} \\
\mathrm{ND}\end{array}$ & $\begin{array}{c}0.21 \\
(0.03)\end{array}$ \\
\hline $\mathrm{Cu}$ & $\begin{array}{l}16 \\
10.41\rangle\end{array}$ & $\begin{array}{l}15.8 \\
(0.20)\end{array}$ & $\begin{array}{l}\text { ND } \\
\text { ND }\end{array}$ & $\begin{array}{c}1.90 \\
(0.20)\end{array}$ & $\begin{array}{c}3.85 \\
(0.55)\end{array}$ & $\begin{array}{l}\text { ND } \\
\text { ND }\end{array}$ & $\begin{array}{l}.3 .4 \\
10.16)\end{array}$ \\
\hline $\mathrm{Zn}$ & $\begin{array}{c}4.5 \\
\{0.15\rangle\end{array}$ & $\begin{array}{l}\mathrm{ND} \\
\mathrm{ND}\end{array}$ & $\begin{array}{l}31.8 \\
(0.07)\end{array}$ & $\begin{array}{l}1.5 \\
(0.2)\end{array}$ & $\begin{array}{l}300 \\
(0.01)\end{array}$ & $\begin{array}{l}\text { ND } \\
\text { ND }\end{array}$ & $\begin{array}{c}4.51 \\
(0.09)\end{array}$ \\
\hline Ga & $\begin{array}{l}\text { ND } \\
\text { ND }\end{array}$ & $\begin{array}{l}\text { ND } \\
\text { ND }\end{array}$ & $\begin{array}{c}0.005 \\
(0.005)\end{array}$ & $\begin{array}{c}0.36 \\
(0.36\end{array}$ & $\begin{array}{c}0,10 \\
(0,10)\end{array}$ & $\begin{array}{l}X D \\
\text { ND }\end{array}$ & $\begin{array}{l}\text { ND } \\
\text { ND }\end{array}$ \\
\hline As & $\begin{array}{l}\text { ND } \\
\text { ND }\end{array}$ & $\begin{array}{l}\text { ND } \\
\text { ND }\end{array}$ & $\begin{array}{c}0.005 \\
(0.005)\end{array}$ & $\begin{array}{c}0.36 \\
(0.30\}\end{array}$ & $\begin{array}{l}0.10 \\
(0.10)\end{array}$ & $\begin{array}{l}\text { No } \\
\text { ND }\end{array}$ & $\begin{array}{l}\text { ND } \\
\text { ND }\end{array}$ \\
\hline $\mathrm{Br}$ & $\begin{array}{c}0,38 \\
\{0,36\}\end{array}$ & $\begin{array}{l}\text { ND } \\
\text { ND }\end{array}$ & $\begin{array}{c}0.44 \\
(0.20)\end{array}$ & $\begin{array}{l}\mathrm{ND} \\
\mathrm{ND}\end{array}$ & $\begin{array}{c}0.85 \\
(0.21)\end{array}$ & $\begin{array}{c}2.26 \\
(0.03)\end{array}$ & $\begin{array}{l}13,8 \\
(0,95)\end{array}$ \\
\hline$C \cdot d$ & $\begin{array}{l}\text { ND } \\
\text { ND }\end{array}$ & $\begin{array}{l}\text { No } \\
\text { ND }\end{array}$ & $\begin{array}{c}0.005 \\
(0.005)\end{array}$ & $\begin{array}{c}0.36 \\
(0.36)\end{array}$ & $\begin{array}{c}0.10 \\
(0.10)\end{array}$ & $\begin{array}{l}\text { ND } \\
\text { ND }\end{array}$ & $\begin{array}{r}0.075 \\
(0.32)\end{array}$ \\
\hline $\mathbf{S b}$ & $\begin{array}{l}\text { ND } \\
\text { ND }\end{array}$ & $\begin{array}{l}\text { ND } \\
\text { ND }\end{array}$ & $\begin{array}{l}114 \\
\quad(0.005)\end{array}$ & $\begin{array}{c}0.02 \\
(0.36)\end{array}$ & $\begin{array}{c}0.15 \\
(0.10)\end{array}$ & $\begin{array}{l}\text { ND } \\
\text { ND }\end{array}$ & $\begin{array}{r}0.034 \\
(0.12)\end{array}$ \\
\hline
\end{tabular}


Table 6. (continued)

\begin{tabular}{|c|c|c|c|c|c|c|c|}
\hline & $\begin{array}{l}\text { Phase II } \\
\text { GA-1 }\end{array}$ & $\begin{array}{c}\text { Phase } 1 \\
\text { GA-1 }\end{array}$ & Mylar & Teflon & $\begin{array}{l}\text { Sticky } \\
\text { filn }\end{array}$ & $\begin{array}{r}\text { Parafin } \\
\text { mylar }\end{array}$ & $w-41$ \\
\hline I & $\begin{array}{c}0.36 \\
(0.10)\end{array}$ & $\begin{array}{l}\text { ND } \\
\text { ND }\end{array}$ & $\begin{array}{l}\text { ND } \\
\text { ND }\end{array}$ & $\begin{array}{l}\text { ND } \\
\text { ND }\end{array}$ & $\begin{array}{l}\text { ND } \\
\text { ND }\end{array}$ & $\begin{array}{c}0.11 \\
(0.70)\end{array}$ & $\begin{array}{l}\text { ND } \\
\text { ND }\end{array}$ \\
\hline La & $\begin{array}{l}\text { ND } \\
\text { ND }\end{array}$ & $\begin{array}{l}\text { ND } \\
\text { ND }\end{array}$ & $\begin{array}{c}0.005 \\
(0.005)\end{array}$ & $\begin{array}{c}0.36 \\
(0.36)\end{array}$ & $\begin{array}{c}0.10 \\
(0.10)\end{array}$ & $\begin{array}{l}\text { ND } \\
\text { ND }\end{array}$ & $\begin{array}{l}N D \\
N D\end{array}$ \\
\hline $\mathrm{Ce}$ & $\begin{array}{l}\text { ND } \\
N D\end{array}$ & $\begin{array}{l}\text { ND } \\
\text { ND }\end{array}$ & $\begin{array}{l}\text { ND } \\
\text { ND }\end{array}$ & $\begin{array}{l}\text { ND } \\
\text { ND }\end{array}$ & $\begin{array}{l}\text { ND } \\
\text { ND }\end{array}$ & $\begin{array}{l}\text { ND } \\
\text { ND }\end{array}$ & $\begin{array}{c}0.11 \\
(0.18)\end{array}$ \\
\hline Hf & $\begin{array}{l}\text { ND } \\
\text { ND }\end{array}$ & $\begin{array}{l}\text { ND } \\
\text { ND }\end{array}$ & $\begin{array}{l}\text { ND } \\
\text { ND }\end{array}$ & $\begin{array}{l}\text { ND } \\
\text { ND }\end{array}$ & $\begin{array}{l}\text { NO } \\
\text { ND }\end{array}$ & $\begin{array}{l}\text { ND } \\
\text { ND }\end{array}$ & $\begin{array}{c}0.82 \\
(0.10)\end{array}$ \\
\hline $\mathrm{Au}$ & $\begin{array}{l}\text { ND } \\
\text { ND }\end{array}$ & $\begin{array}{l}\text { ND } \\
\text { ND }\end{array}$ & $\begin{array}{l}\text { ND } \\
\text { ND }\end{array}$ & $\begin{array}{l}\text { ND } \\
\text { ND }\end{array}$ & $\begin{array}{l}\text { ND } \\
\text { ND }\end{array}$ & $\begin{array}{l}\text { ND } \\
\text { ND }\end{array}$ & $\begin{array}{c}2.44 \\
(0.07)\end{array}$ \\
\hline $\mathrm{Hg}$ & $\begin{array}{r}0.39 \\
(0.5)\end{array}$ & $\begin{array}{l}12.6 \\
(0.06)\end{array}$ & $\begin{array}{l}2.6 \\
(0.50)\end{array}$ & $\begin{array}{c}1.2 \\
(0.5)\end{array}$ & $\begin{array}{c}3.0 \\
(0.5)\end{array}$ & $\begin{array}{l}\text { ND } \\
\text { ND }\end{array}$ & $\begin{array}{c}0.16 \\
(0.30)\end{array}$ \\
\hline Th & $\begin{array}{l}\text { ND } \\
\text { ND }\end{array}$ & $\begin{array}{l}\text { ND } \\
\text { ND }\end{array}$ & $\begin{array}{l}\text { ND } \\
\text { ND }\end{array}$ & $\begin{array}{r}0.007 \\
(0.35)\end{array}$ & $\begin{array}{l}0 \\
0\end{array}$ & $\begin{array}{l}\text { ND } \\
\text { ND }\end{array}$ & $\begin{array}{c}0.025 \\
(0.27)\end{array}$ \\
\hline
\end{tabular}

which represents the population of filter (or impactor) media which was used in the sampling under field conditions.

The experience gained during Phase I showed that a better statistical sampling of the pool of washed CA-1 filters was in order for Phase II. Accordingly, the following studies were carried out.

Phase II, GA-1, Series 1

A representative group of 13 washed filtere which had first been analyzed at LBL was anelyzed with the results shown in Table ?. Of particular intereat is the extreme variabllity in the Na values for the 13 fliter's, the rangt heing an order of magnitude. The $95 \%$ confidence interval or two standas'd deviations is in excess of $200 \%$. Also, $\mathrm{Cu}, \mathrm{V}$, and $\mathrm{Br}$ show high variability, although not aB severe as that of $\mathrm{Na}$,
When these blank values were used in computing the results for particulate loadings on the after and total filters, it became apparent that they were too high since witection limits were being reported where they were not expected. Comparison of these blank values to those obtained for Phase I blanks gave ratios as high as 4.5. No reasonable explanation was found for the se fiscrepancies. It $\mathrm{x}$ as decided to exumine another representative group of blanks.

Phase II, GA-I, Series 2

Eignt additional GA-1 blank filters were subjected to analysis. The results are shown in Table 8. Again, extremely high variability was seen among the $\mathrm{Na}$ values as well as $\mathrm{Cu}, \mathrm{Al}, \mathrm{Ca}$, and $\mathrm{Mn}$. However, the average values produced more believable results when applied to 
Table 7. AIHL Phase II GA-1 lab blanks - first set $\left(\mathrm{ng} / \mathrm{cm}^{2}\right.$ )

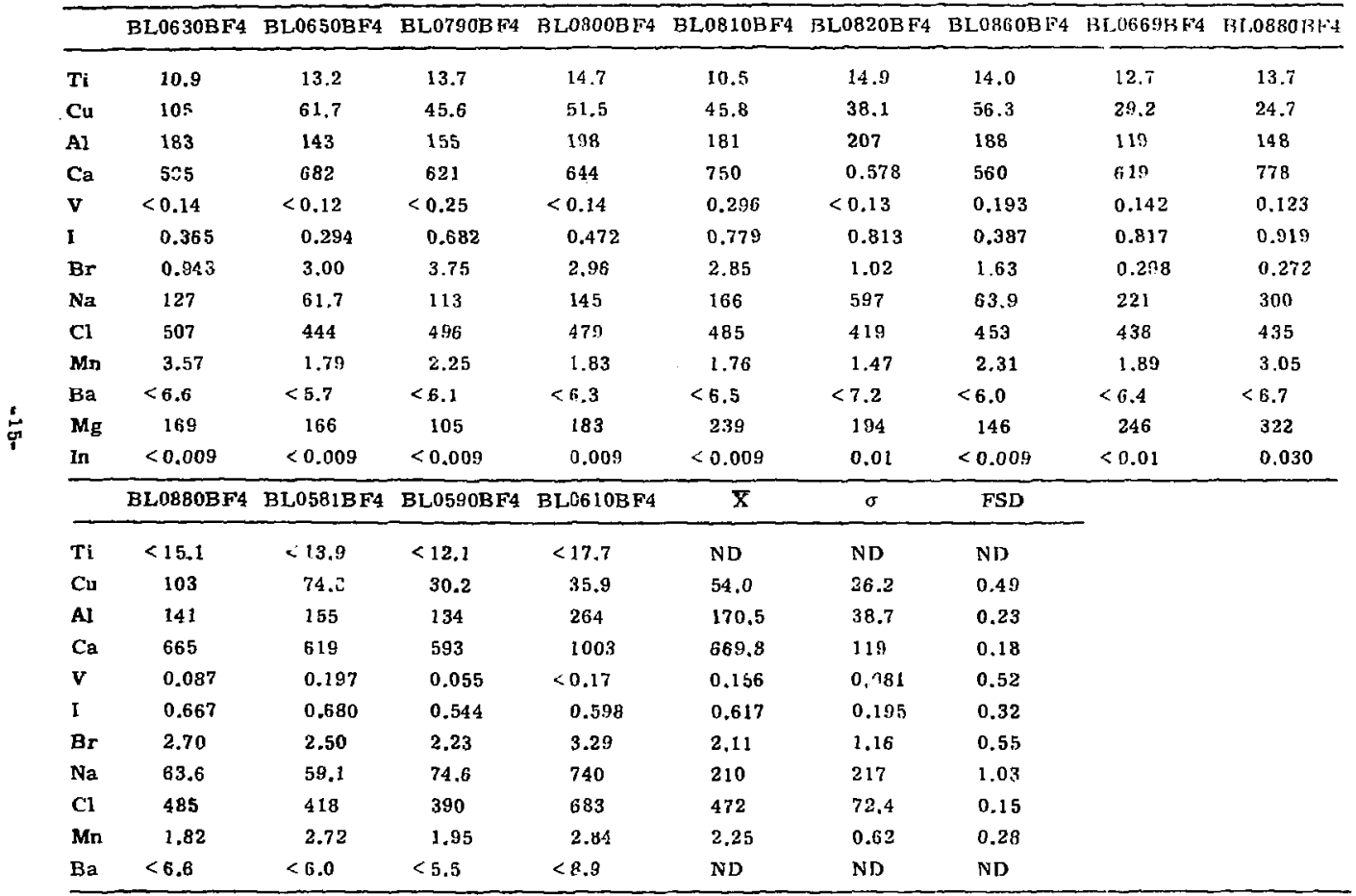


Table 8, AIH:. Phase II GA-1 lab blanks - second set $\left(\mathrm{ng} / \mathrm{cm}^{2}\right)$.

\begin{tabular}{|c|c|c|c|c|c|c|c|c|c|c|c|}
\hline & BL0969BF & BL0979BF & BLo989B F & BLogegf F & BL1009BI. & BI,LONBL & BL.1029BI. & BL1079BL (n & $\underset{n g, ; m}{\text { Avg }}$ & $\sigma$ & FSD \\
\hline $\mathbf{T i}$ & $<9.0$ & $<7$ & $<8$ & $<7$ & $\begin{array}{l}9.25 \\
0.82\end{array}$ & $<9$ & $<9.7$ & $<8$ & ND & ND & ND \\
\hline $\mathbf{M g}$ & $\begin{array}{l}115 \\
0.477\end{array}$ & $<87$ & $<92$ & 89 & $\cdot 84$ & $\begin{array}{l}72 \\
0.63\end{array}$ & $<123$ & $\begin{array}{l}88.5 \\
0.49\end{array}$ & ND & ND & ND \\
\hline $\mathrm{Cu}$ & $\begin{array}{l}13.4 \\
0.20\end{array}$ & $\begin{array}{l}9.63 \\
0.22\end{array}$ & $\begin{array}{l}22.6 \\
0.12\end{array}$ & $\begin{array}{l}12.7 \\
0.18\end{array}$ & $\begin{array}{l}18.8 \\
0.13\end{array}$ & $\begin{array}{l}26.7 \\
0.12\end{array}$ & $\begin{array}{l}11.8 \\
0.27\end{array}$ & $\begin{array}{l}9.3 \\
0.27\end{array}$ & 15.6 & 6.5 & 0.42 \\
\hline v & $<0.08$ & $<0,06$ & $<0.07$ & $<0,06$ & $<0.06$ & $<0.08$ & $<0.09$ & $<0.07$ & ND & ND & ND \\
\hline Al & $\begin{array}{l}64.7 \\
0.046\end{array}$ & $\begin{array}{l}31.2 \\
0.055\end{array}$ & $\begin{array}{l}32.5 \\
0.055\end{array}$ & $\begin{array}{l}23.7 \\
0.06\end{array}$ & $\begin{array}{l}22.1 \\
0.06\end{array}$ & $\begin{array}{l}43.7 \\
0.05\end{array}$ & $\begin{array}{l}72.0 \\
0.05\end{array}$ & $\begin{array}{l}36.7 \\
0.05\end{array}$ & 40.8 & 18.4 & 0.45 \\
\hline $\mathrm{Ca}$ & $\begin{array}{l}140 \\
1.11\end{array}$ & $\begin{array}{l}156.3 \\
0.88\end{array}$ & $\begin{array}{l}72.7 \\
0.52\end{array}$ & $\begin{array}{l}176.1 \\
0.29\end{array}$ & $\begin{array}{l}152.5 \\
1.04\end{array}$ & $\begin{array}{l}168.7 \\
0.86\end{array}$ & $\begin{array}{l}251.8 \\
1.04\end{array}$ & $\begin{array}{l}289.2 \\
0.23\end{array}$ & 175.0 & 71.8 & 0.41 \\
\hline $\mathbf{B a}$ & $<4.2$ & $<3.4$ & $<3.5$ & $<3.5$ & $<3.4$ & $<3.7$ & $<4.6$ & $<3.7$ & ND & ND & ND \\
\hline I & $<0.28$ & $<0.22$ & $<0.22$ & $\begin{array}{l}0.30 \\
0.37\end{array}$ & $<0.22$ & $<0.23$ & $<0.31$ & $\begin{array}{l}0.34 \\
0.32\end{array}$ & ND & ND & ND \\
\hline $\mathrm{Br}$ & $<0.82$ & $<0.7$ & $<0.7$ & $<0.7$ & $\begin{array}{l}0.48 \\
0.03\end{array}$ & $<0.72$ & $<0.91$ & $\begin{array}{l}0.28 \\
0.03\end{array}$ & ND & ND & ND \\
\hline ln & $<0.03$ & $<0.005$ & $<0.005$ & $<0.005$ & $<0.005$ & $<0.006$ & $<0.007$ & $<0.006$ & ND & ND & ND \\
\hline $\mathbf{N a}$ & $\begin{array}{l}124.1 \\
0.05\end{array}$ & $\begin{array}{l}23.6 \\
0.15\end{array}$ & $\begin{array}{l}7.74 \\
0.31\end{array}$ & $\begin{array}{l}24.6 \\
0.14\end{array}$ & $<5.5$ & $\begin{array}{l}9.4 \\
0.29\end{array}$ & $\begin{array}{l}185.5 \\
0.05\end{array}$ & $\begin{array}{l}11.3 \\
0.26\end{array}$ & 55.0 & 70 & 1.1 \\
\hline Cl & $\begin{array}{l}153.3 \\
0.07\end{array}$ & $\begin{array}{l}144.9 \\
0.07\end{array}$ & $\begin{array}{l}157.5 \\
0.06\end{array}$ & $\begin{array}{l}167.6 \\
0.06\end{array}$ & $\begin{array}{l}143.3 \\
0.07\end{array}$ & $\begin{array}{l}161.9 \\
0.07\end{array}$ & $\begin{array}{l}212.2 \\
0.06\end{array}$ & $\begin{array}{l}176.6 \\
0.06\end{array}$ & 160 & 34 & 0.21 \\
\hline $\mathbf{M n}$ & $\begin{array}{l}0.656 \\
0.99\end{array}$ & $\begin{array}{l}0.53 \\
0.37\end{array}$ & $\begin{array}{l}0.64 \\
1.04\end{array}$ & $\begin{array}{l}0.38 \\
0.52\end{array}$ & $<0.42$ & $<0.47$ & $<0.57$ & $\begin{array}{l}0.52 \\
0.40\end{array}$ & 0.54 & 0.11 & 0.21 \\
\hline
\end{tabular}


the analysis of particulate matter collected on the after and totn filters. Comparison with Phase [ $C A-1$ hlanks and Phase Il field blanks tends 10 support the validity of the blank values for this set.

Fven though the expected error for individual determinations may have been rather small, the standard deviation of the eight measurements must be used in the computer program library which describes the average blank. Consequently, as the measured trace element approaches the blank value, the probable error associated $w i$ th the blank begins to predominate and the reported trace element will have a large prubable error associated with it.

Field Blanks

Data for 28 field blanks are presented in Table 9. Again, Na showed extremely bigh variability. Since these blanks were exposed to field conditions, the variability across any single element cannot necessarily be attributed solely to the innate variability of the unexposed blanks.

Table 10 is a summary of the rield blank data showing moans, standard deviations and fractional standard deviations. The means for the: second series of laboratory blanks are inclucied for comparison.

When the lield blank mean is ratioed to the lab blank mean, all cases show values greater than unity, with $\mathrm{Br}$ exceptionally high (16:1). Since we are dealing with statistical sampling, inspection of these ratios cannot glve a satisfactory answer to the question of whether the means are significuntly different. Using the student-t test at the level of $\alpha=0.05$ (95\% confidence). It is found that all but $M n$, both meang for $\mathrm{Na}, \mathrm{Mg}$, and $I$ can be said to have different means $\left(\mu_{1} \neq \mu_{2}\right)$.
Thus, we can say that to a confidence level of 0.95 , something occurred to the field blanks to cause $\mathrm{Cu}, \mathrm{Al}, \mathrm{Ca}, \mathrm{Cl}$, and $\mathrm{Br}$ to be elevated relative to the laboratory blanks. This conclusion should be tempered quite a bit considering the unequal sample sizes in the lab fleld blanks and the relutively small number of lab blanks. If further hypothesizing is attempted, it is suggested that a separate study be done using larger sampling; or perhaps better still, using the same filters in both laboratory and field studies and analyzing the filters before and after they are subjected to field conditions.

\section{QUALITY ASSURANCE}

\section{Bromine-Loss Test}

Tests were carried out on a high volume Whatman 41 filter run in Livermore for 24 hours during a rainy day. Two 1 -inch circles were cut out of the paper and run on the LLL Radiochemistry Division isotopic-source XRFA system on the same day. The circles were then inserted into the LPTR for a 2-minute irradiation and later counted again on the XRFA system. The Br loading on the 1-inch circles is as follows:

Before ( $\mu \mathrm{g})$ After ( $\mu \mathrm{g})$. Difference ( $\left.\sigma_{0}\right)$

No. $15.09 \pm 0.255 .14 \pm 0.26+(0.98 \pm 6.9)$ No. $25.45 \pm 0.275 .16 \pm 0.26-(5.3 \pm 6.8)$

From these results we conclude that $\mathrm{Br}$ loss, if any, caused by a 2-minute reactor irradiation is less than $5 \%$. We hope to carry out $\mathrm{Br}$ determinations with smaller errors in the near future.

Tests were also performed to compare the absolute determination of $\mathrm{Br}$ XRFA and NAA: 
Table 9. Field blanks - Phase II, total (ng/blank).

\begin{tabular}{|c|c|c|c|c|c|c|c|c|c|c|c|}
\hline & TA0759BF & TB0770BF & TC0782B F & TD0794BE & UF0817BF & UGO833BF & VH1049BF & VH1051BF & VI11203F & VJ0859BF & VJ1059BF \\
\hline$\dot{\mathrm{Mg}}$ & w1 2 & $<699$ & $<688$ & $<578$ & $<555$ & 609 & 450 & $<533$ & $<525$ & $<597$ & $<509$ \\
\hline $\mathrm{Cu}$ & 91.5 & 123 & 85 & 67 & 67 & 197 & 65 & 68 & 58 & 152 & 62 \\
\hline AI & 266 & 529 & 467 & 298 & 263 & 272 & 172 & 192 & 19.5 & 303 & 226 \\
\hline $\mathrm{Ca}$ & 1303 & 1873 & 972 & 627 & 973 & 716 & 1098 & 1593 & 748 & 1730 & 1298 \\
\hline Ti & $<48$ & $<57$ & $<54$ & $<\mathbf{5 2}$ & $<46$ & $<54$ & $<43$ & $<46$ & $<46$ & $<49$ & $<41$ \\
\hline $\mathbf{v}$ & $<0.41$ & $<<0.51$ & $<0.48$ & $<0.44$ & 0.34 & $<0.42$ & $<0.36$ & $<0.38$ & $<0.39$ & 0.093 & $<0.37$ \\
\hline 1 & 2.4 & 3.0 & 3.0 & 3.0 & 2.5 & 2.8 & 2,8 & $<1.4$ & $<1.4$ & 1.2 & 1.2 \\
\hline $\mathbf{B r}$ & 12.6 & 30 & 33.4 & 23.7 & 14.6 & 31 & 13.3 & 13.4 & 14.6 & 7.3 & 11.8 \\
\hline $\mathrm{Na}^{\mathrm{Q}}$ & 257 & 365 & 689 & 351 & 386 & 431 & 94 & 146 & 64 & 102 & 46 \\
\hline $\mathrm{Cl}^{\mathrm{a}}$ & 969 & 978 & $10 B 0$ & 1045 & 837 & 1054 & 876 & 962 & 1021 & 854 & 836 \\
\hline Mn & 3.1 & 6.6 & 2.9 & 3.2 & 3.7 & 6.2 & 3.7 & 3.7 & 5.0 & $<2.4$ & $<2.3$ \\
\hline $\mathbf{B a}$ & $<21$ & $<24$ & $<24$ & $<24$ & $<21$ & $<24$ & $<20$ & $<22$ & $<21$ & $<21$ & $<19$ \\
\hline \multirow[t]{2}{*}{ In } & $<0.031$ & $<0.032$ & $<0.032$ & $<0.033$ & $<0.028$ & $<0.032$ & $<0.03$ & $<0.032$ & $<0.03$ & $<0.03$ & $<0.028$ \\
\hline & WK1106BF & W'L1043BF & WLI046BF & Cl0855B F & FI08383F & CK0907BF & DK0891BF & EK0928BF & FK0889BF & GK10173F & \\
\hline $\mathbf{M g}$ & 432 & $<526$ & $<857$ & $<551$ & $<639$ & $<637$ & $<724$ & 691 & $2 ! 9$ & 682 & \\
\hline $\mathrm{Cu}$ & 54 & 68 & 71 & 52 & 37.6 & 113.6 & 245 & $17 n$ & 204 & 146 & \\
\hline Al & 167 & 225 & 484 & 238 & 400 & 353 & 530 & 346 & 344 & 265 & \\
\hline $\mathrm{Ca}$ & 1025 & 1056 & 1658 & 1.371 & $90 !$ & 1379 & 1465 & 1418 & 1403 & 1738 & \\
\hline $\mathbf{T i}$ & $<42$ & $<44$ & 39 & 39 & $<56$ & c 56 & $<65$ & $<59$ & $<60$ & $<54$ & \\
\hline v & $<0.36$ & $<0.39$ & $<0.60$ & $<0.40$ & 0.52 & $<0.047$ & 0.79 & 0.912 & 0.347 & 0.62 & \\
\hline 1 & 2.7 & 5.7 & 8.2 & 3.0 & 2.7 & 1.9 & 4.1 & 3.6 & 3.3 & 2.4 & \\
\hline
\end{tabular}


Table 9. (continued).

\begin{tabular}{|c|c|c|c|c|c|c|c|c|c|c|}
\hline Br & 13.4 & 13.2 & 27 & 45 & 51 & 44 & 54 & 63 & 59 & 42 \\
\hline $\mathrm{Na}^{\mathrm{a}}$ & 145 & 138 & 2297 & 348 & 332 & 151 & 252 & 294 & 231 & 105 \\
\hline $\mathrm{Cl}^{\mathrm{a}}$ & 896 & 901 & 2149 & 923 & 4 & 1033 & 1220 & 1161 & 1226 & 1006 \\
\hline $\mathbf{M n}$ & 3.2 & $<2.5$ & 6.1 & 5.8 & 3.1 & 6.1 & 8.4 & 6.8 & 7.3 & 4.2 \\
\hline $\mathbf{B a}$ & $<20$ & $<21$ & $<34$ & $<24$ & $<26$ & $<25$ & $<28$ & $<28$ & $<28$ & $<24$ \\
\hline In & $<0.032$ & $<0.029$ & $<0.05$ & $<0.032$ & $<0.034$ & $<0.032$ & $<0.038$ & $<0.035$ & $<0.036$ & $<0.036$ \\
\hline & CFO697BF & DF0708BF & CEO6 15TF & DE0571BF & EE05.52B। & J'l:0626BF & GF0561BF & $\bar{x}$ & $\sigma$ & FSD \\
\hline $\mathbf{M g}$ & $<628$ & $<805$ & $<693$ & $<566$ & $<716$ & 1014 & 715 & 603 & 222 & 0.37 \\
\hline $\mathrm{Cu}$ & 132 & 90 & 171 & 104 & 105 & 143 & 53 & 107.5 & 54 & 0.50 \\
\hline $\mathbf{A 1}$ & 312 & 592 & 408 & 145 & 503 & 420 & 359 & 331 & 124 & 0.37 \\
\hline $\mathbf{C a}$ & 1428 & 1123 & 1652 & 657 & 1386 & 1067 & 1107 & 1260 & 365 & $0.2 !$ \\
\hline $\mathbf{T i}$ & 67 & $<66$ & $<60$ & $<47$ & $<59$ & $<57$ & $<54$ & $\mathrm{ND}$ & ND & ND \\
\hline $\mathbf{V}$ & $<0.45$ & 0.44 & $<0.50$ & 0.42 & 0.56 & 0.51 & $<0.47$ & 0.505 & 0.222 & 0.49 \\
\hline 1 & 3.0 & 4.6 & 2.2 & 2.1 & 2.8 & $3 . F$ & 2.6 & 3.1 & 1.4 & 0.41 \\
\hline $\mathbf{B r}$ & 40 & 37 & 37 & 28 & 35 & 34 & 37 & 30.9 & 15,6 & 0.50 \\
\hline $\mathrm{Na}^{\mathrm{a}}$ & 247 & 1086 & 787 & 346 & 539 & 2135 & 763 & $\begin{array}{l}402 \\
304\end{array}$ a & $\begin{array}{l}445 \\
204\end{array}$ & $\begin{array}{l}1.1 \\
0.67\end{array}$ \\
\hline $\mathrm{Ci}^{\mathrm{a}}$ & 1194 & 1487 & 1362 & 1277 & 1214 & 1256 & 1192 & 1106 & $\begin{array}{l}204 \\
265 \\
153\end{array}$ & $\begin{array}{l}0.23 \\
0.15\end{array}$ \\
\hline $\mathbf{M n}$ & 7.4 & 8.9 & 3.2 & 4.7 & $5: \therefore$ & 5.2 & 4.2 & 5.3 & 1.7 & 0.32 \\
\hline $\mathrm{Ba}$ & $<25$ & $<29$ & 28 & $<25$ & $<25$ & $<25$ & $<26$ & ND & NI) & ND \\
\hline In & $<0.033$ & 0.041 & 0.039 & $<0.036$ & $<0.037$ & $\times 0.0,36$ & $<0.036 i$ & ND & ND & NI) \\
\hline
\end{tabular}

\footnotetext{
${ }^{2} \mathrm{X}$ and $\sigma$ were calculated twice, the first time using all values and the second time nmitting the two highest values.
} 
Table 10. Fleld blank aummary - Phase 11.

\begin{tabular}{|c|c|c|c|c|c|c|c|}
\hline & $\begin{array}{l}\text { Avg } \\
(\mathbf{n g})\end{array}$ & $\sigma$ & FSD & $\underset{\left(\mathrm{ng} / \mathrm{cm}^{2}\right)}{\text { Avg }}$ & $\begin{array}{l}\text { GA-1 } \\
\text { Phase II } \\
\text { lab blank } \\
\text { avg } \\
\left.\text { (ng } / \mathrm{cm}^{2}\right)\end{array}$ & $\begin{array}{l}\text { Fleid blank/ } \\
\text { lab blank }\end{array}$ & $\begin{array}{l}\text { By t-Test, } \\
H_{0}: \mu 1=\mu_{2} \\
\text { at }=0.05\end{array}$ \\
\hline $\mathbf{M g}$ & 603 & 222 & 0.37 & 119 & $92^{c}$ & 1.3 & $\mu_{1}=\mu_{2}$ \\
\hline $\mathrm{Cu}$ & 108 & 54 & 0.50 & 21,3 & 16 & 1.3 & $\mu_{1} / \mu_{2}$ \\
\hline Al & 331 & 124 & 0.37 & 65 & 41 & 1.6 & $\omega_{1} \mu_{2}$ \\
\hline $\mathrm{Ca}$ & 1260 & 365 & 0.29 & 240 & 176 & 1.4 & $\mu_{1} \neq \omega_{2}$ \\
\hline $\mathbf{T} \mathbf{i}$ & ND & ND & ND & ND & ND & ND & \\
\hline $\mathrm{v}$ & 0.51 & 0.22 & 0.43 & 0.10 & ND & vo & \\
\hline I & 3.1 & 1.4 & 0.45 & 0.61 & $0.32^{c}$ & 1.91 & $\mu_{1}=\mu_{2}$ \\
\hline $\mathrm{Br}$ & 31 & 16 & 0.52 & 6.1 & $0.38^{c}$ & 16.1 & $\mu_{1} \mu_{2}$ \\
\hline $\mathrm{Na}^{\mathrm{a}}$ & 402 & 445 & 1.11 & 79.3 & 55 & 1.4 & $\mu_{1}=\mu_{2}$ \\
\hline $\mathrm{Na}^{\mathrm{b}}$ & 304 & 204 & 0.67 & 60 & 55 & 1.1 & $u_{1}=u_{2}$ \\
\hline $\mathrm{Cl}^{\mathrm{a}}$ & 1106 & 265 & 0.24 & 218 & 158 & 1.4 & $\mu_{1} \neq \mu_{2}$ \\
\hline$C l^{b}$ & $: r 51$ & 153 & 15 & 207 & 158 & 1.3 & $\mu_{1} * \mu_{2}$ \\
\hline$M n$ & 5.3 & 1.7 & 0.32 & 1.04 & 0.82 & 1.3 & $\omega_{1}=\mu_{2}$ \\
\hline $\mathrm{Ba}$ & ND & ND & iND & ND & ND & ND & " \\
\hline In & ND & ND & ND & ND & ND & $x D$ & \\
\hline
\end{tabular}

\footnotetext{
ancludes all values.

${ }^{b}$ Excludes two highest values.

These values were derived by averaging those out of eight filters which had detectable Bromine, lodine, or Magnesium.
}

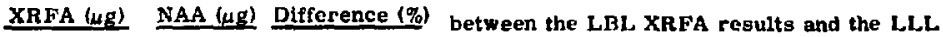

No. $3 \quad 5.42 \pm 0.27 \quad 5.81 \pm 0.29 \quad 6.7 \pm 6 . \theta$ No. $4 \quad 5.39 \pm 0,27 \quad 6.03 \pm 0.30 \quad 10.6 \pm 0.6$ NAA results for Br was reasonable within the error limits: 6

These results geem to indicate a rlight discrepancy between the LLL NAA and XRFA analyses. However, to be able to reach a definite conclusion, more accurate tegts must be conducted. Interlaboratory comparisons on high-volume Whatman 41's in Phase I demonstrated that the agreement

Riverside
Pasadena
Fresno
Bakerafield
Berkeley (AA0006)
Berkeley (AA0007)

Difference (\%) (NAA - XRFA)

$+17+14$

$+17 \pm 16$

$+12 \pm 11$

$-14 \pm 11$

$-14 \pm 10$

$+10 \pm 11$ 
Adefitional testa nere alsi, run tic deter-

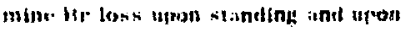
stewsige in an evacunted destecatise. Whatnan allerex were allowed ta stand

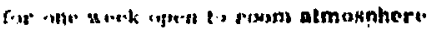

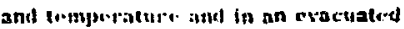

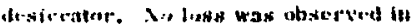

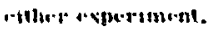

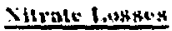

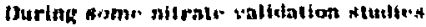
in AC'IlEX, a question was raised ax [" the valatile los; of nitrite flurting IXAA. Samples are kubjected lo moskrake heating - $135 \times 1.7$, lo gamma sust neutron irrullialion dueling NAA, all of wefleh migh caume nitrate lass.

To asteds direct, the- Intportance of nitrate loan undsr XAA candition, thres: filcre samples rollocled during the 1072 sampling perilud IAClllsx-11 in ltiverside, were split in half, and ane ploce way wabjerted to NAA. The pieces Werv then analyzen for nitrate with the restules ats collowis:

\begin{tabular}{|c|c|}
\hline Salmpie & $\mathrm{NO}_{3}-/ \mathrm{NU}_{3}-$ (antor $\left.\mathrm{NAA}\right)$ \\
\hline 1 & 1.02 \\
\hline 2 & 0.89 \\
\hline 3 & 0.78 \\
\hline
\end{tabular}

(') carly these results fall to roveal a signiftcant loss of nitrate by exposure to XAA cundition. However, the samples avallable for thia study had been maintained (in rlosed Millipore filter boxes) at foom temperalure for nearly two years which may have made them inappropulate for this study.

\section{VALIDATION}

For the determination of the overa!l accuracy of the uae of INAA for the atrosth characteriration atudy, we had aceess to three different types of verification. The first of these verifications was to andiye some standard material and crnpole nur masured values to thase coettifted by the anent issuing the standard. In our cass, we analyzed 18 chard loaves an certifled by thi- National llureatu of Standardn.

The secend approseh was to partcipa'. in an interlaboratory compnrition of anas. "Jerment determinations on various standardized watuples. Tis was done fror coal dust and ny ash in me series, and far Qravimetric standard solutions in ansther.

Hinally, and perhaps of major interest. wat the passibility of inleyermpisis isn within the experimental program. This insolves direct comparison of elements determined in the same sample by differ wht anaigtical techniques and somparison of an sverall vicw is data produced by differant cecluniquas, not necestarily looking at the same elements.

\section{Ni3S Orchard I.caves (SkMi-15711}

Samples of NBS atandard reference insterial - orchari leaves - rere analyzod. The values shown in Table 11 are averages of throse to live replicates. The ABs cortificd ralues are also given. The values an parcntheses are for informutional value only and are not certifled. The experimentai ertors are equal to two staniard deviations or onehalf the range of the data, whichever is ereater.

NBS-EPA-Imtercomparison Study of Coa Dust (StiL Tosk) and biy Ach(stim I633)

A "round-robtn" intercomparlson study was sponsored jointly by the National 
Table 11. National Bureau of Staridards SRM-1571 orchard leaves ( $\mu \mathrm{g} / \mathrm{g})$.

\begin{tabular}{|c|c|c|}
\hline & LLL & NBS \\
\hline Al & $341 \pm 39$ & $(350)$ \\
\hline $\mathrm{Ca}$ & $20400 \pm 1000$ & $20900 \pm 300$ \\
\hline $\mathbf{B a}$ & $42.7 \pm 4.7$ & \\
\hline $\mathrm{Mg}$ & $6600 \pm 500$ & $6200 \pm 200$ \\
\hline $\mathbf{B r}$ & $13.0 \pm 2.6$ & (10) \\
\hline$v$ & $0.675 \pm 0.029$ & \\
\hline In & $0.17 \pm 0.05$ & \\
\hline $\mathrm{Na}$ & $89 \pm 9$ & $82 \pm 6$ \\
\hline $\mathrm{Fe}$ & $330 \pm 40$ & $300 \pm 20$ \\
\hline $\mathrm{Cl}$ & $635 \pm 47$ & $(700)$ \\
\hline $\mathrm{Mn}$ & $n 5=3$ & $91 \pm 4$ \\
\hline As & $8.8 \pm 3.4$ & $14 \pm 2$ \\
\hline K & $12200 \pm 3600$ & $14700 \pm 300$ \\
\hline
\end{tabular}

Bureau of Standards and the Environmental Protection Agency. The standards were coal dust, fly ash, gasoline, and fuel oil. LLL participated in the measurements of coal dust and ny ash. Our report is reproduced herein, together with the determinations of ather laboratories, We also indicate the values which have been certified by NBS. These data have been presented ${ }^{7}$ and are published. ${ }^{8}$ The results of the determinations are given in Tables 12, 13, and 14. The errors inindicated are derived from the dispersion of the separately determined replicates. The absolute values of errors represent either one-half the range or two standard deviations, whichevar is the iarger.

Table 12 shows average valucs of all the elements which were determined, including those requested by NBS.

Tables 13 and 14 show the measurements on individual samples, together with the total error for that part!cular mensure-
Table 12, LLL results for NBS/EPA standards coal and ny ash done by INAA (average values).

\begin{tabular}{llc}
\hline \multirow{2}{*}{ Element } & $\begin{array}{l}\text { SRM-1632 } \\
\text { Coal (ppm) }\end{array}$ & FrM-1633 \\
\hline
\end{tabular}

\begin{tabular}{lll}
$\mathrm{Al}$ & $20000 \pm 1130$ & $123000 \pm 6.320$ \\
$\mathrm{As}$ & $5.04 \pm 0.66$ & $51.7 \pm 3.3$ \\
$\mathrm{Ba}$ & $327 \pm 19$ & $2610 \pm 170$ \\
$\mathrm{Br}$ & $18.6 \pm 2.4$ & $\mathrm{ND}$ \\
$\mathrm{Ca}$ & $4220 \pm 670$ & $44800 \pm 2600$ \\
$\mathrm{Ce}$ & $18.5 \pm 0.65$ & $135 \pm 7$ \\
$\mathrm{Cl}$ & $758 \pm 62$ & $\mathrm{ND}$ \\
$\mathrm{Co}$ & $6.04 \pm 0.29$ & $42.0 \pm 1.9$ \\
$\mathrm{Cr}$ & $19.3 \pm 0.97$ & $126 \pm 10$ \\
$\mathrm{Eu}$ & $0.321 \pm 0.011$ & $2.22 \pm 0.20$ \\
$\mathrm{Fe}$ & $8180 \pm 370$ & $58000 \pm 3030$ \\
$\mathrm{Hf}$ & $0.724 \pm 0.060$ & $5.79 \pm 0.38$ \\
$\mathrm{In}$ & $0.196 \pm 0.120$ & $0.321 \pm 0.100$ \\
$\mathrm{~K}$ & $2260 \pm 76$ & $13840 \pm 640$ \\
$\mathrm{Ia}$ & $9.10 \pm 0.38$ & $65.0 \pm 6.6$ \\
$\mathrm{Mn}$ & $47.6 \pm 3.4$ & $506 \pm 23$ \\
$\mathrm{Na}$ & $313 \pm 22$ & $2800 \pm 210$ \\
$\mathrm{Sb}$ & $4.1 \pm 5.3$ & $6.38 \pm 0.41$ \\
$\mathrm{Sc}$ & $3.94 \pm 0.19$ & $28.0 \pm 1.7$ \\
$\mathrm{Sm}$ & $1.4 \mathrm{~B} \pm 0.07$ & $11.1 \pm 0.7$ \\
$\mathrm{Th}$ & $2.97 \pm 0.17$ & $23.3 \pm 1.3$ \\
$\mathrm{Ti}$ & $1060 \pm 120$ & $7220 \pm 670$ \\
$\mathrm{~V}$ & $38.3 \pm 3.3$ & $244 \pm 24$ \\
$\mathrm{~W}$ & $\mathbf{0 . 6 2} \pm 0.27$ & $3.5 \pm 1.1$ \\
\hline & &
\end{tabular}

ment. This er ror is given as one standard deviation and includes procedural errors and errors assoclated with peak area determination.

Tables 15 and 16 show the results reported by other laboratorles and LLL.

\section{Interlaboratory Comparison of standard samples}

A comparison of trace element concentrations determined by five different 
Table 13. LLL. results for NI3S/EPA standard cral (SRM-1632) d and by IXAA.

\begin{tabular}{|c|c|c|c|c|c|}
\hline & $\frac{\text { Replicate } 1}{(\mathrm{ppm})}$ & $\frac{\text { Replicate } 2}{(\mathrm{ppm})}$ & $\frac{\text { Replicate } 3}{(\mathrm{ppm})}$ & $\frac{\text { Replir:ate } 4}{\text { (p) }}$ & $\frac{\text { R(cplicats } 5}{\text { (ppm) }}$ \\
\hline $\mathrm{Al}$ & $1 \$ 1200 \pm 550$ & $20500 \pm 590$ & $20600 \pm 540$ & $19900 \pm 580$ & $19400 \pm 570$ \\
\hline$A s$ & $4.65 \pm 0.42$ & $4.74 \pm 0.37$ & $4.55 \pm 0.38$ & $5.45 \pm 0.42$ & $5.23=11.40$ \\
\hline Ba & $312 \pm 18$ & $336 \pm 20$ & $331+19$ & $322 \div 1 n$ & $333=20$ \\
\hline $\mathrm{Hr}$ & $18.7 \pm 2.9$ & $17.2 \pm 2.8$ & $17 . n=2.8$ & $20.1=3.2$ & $19.3+2.3$ \\
\hline $\mathrm{Ca}$ & $4350 \pm 370$ & $4640 \pm 406$ & $4180 \pm 370$ & $3720 \pm 340$ & $4220=380$ \\
\hline$C^{\prime} \mathrm{e}$ & $18.6 \pm 0.3$ & $18.2+0.3$ & $18.2 \pm 0.3$ & $1 ! .0 \pm 0.2$ & $18.6=0.3$ \\
\hline $\mathrm{Cl}$ & $724 \pm 2 !$ & $791 \pm 30$ & $800 \pm 32$ & $75 f_{i} \pm 30$ & $762 \pm 30$ \\
\hline C's & $0.08 \pm 0.09$ & $5.83 \pm 0.08$ & $5.96 \pm 0.09$ & $6.17 \pm 0.08$ & $6.17 \times 0.10$ \\
\hline $\mathrm{Ch}$ & $19.1 \pm 0.3$ & $18.7 \pm 0.4$ & $19.1 \pm 0.3$ & $20.0 \pm 0.3$ & $19.4 \pm 0.5$ \\
\hline Eu & $0.324 \pm 0.008$ & $0.321 \pm 0.007$ & $0.318 \pm 0.007$ & $0.329 \pm 0.007$ & $0.315 \pm 0.008$ \\
\hline Fe & $8110 \pm 160$ & $7940 \pm 160$ & $8120 \pm 170$ & $8380 \pm 170$ & $8350 \pm 180$ \\
\hline $\mathrm{Hf}$ & $0.682 \pm 0.120$ & $0.713 \pm 0.125$ & $0.748 \pm 0.131$ & $0.721 \pm 0.125$ & $0.757=0.135$ \\
\hline $\ln$ & $0.172 \pm 0.015$ & $0.215 \pm 0.013$ & $0.266 \pm 0.014$ & $0,107 \pm 0,010$ & $0.219 \pm 0.012$ \\
\hline K & $2230 \pm 230$ & $2240 \pm 210$ & $2250 \pm 240$ & $2240 \pm 210$ & $2320 \pm 230$ \\
\hline 1.2 & $4.41 \pm 0.68$ & $9.03 \pm 0.66$ & $8.99 \pm 0.67$ & $9.12 \pm 0.68$ & $8.93 \pm 0.67$ \\
\hline Mn & $45.7 \pm 1.5$ & $50,2 \pm 1.6$ & $4^{\prime} 7.6 \pm 1.6$ & $46.7 \pm 1.5$ & $47.7 \pm 1.5$ \\
\hline $\mathrm{Na}$ & $298 \pm 13$ & $304 \pm 14$ & $322 \pm 14$ & $322 \pm 14$ & $317 \pm 14$ \\
\hline Sb & $0.8 \div \div \pm 0.041$ & $7.03 \pm 0.14$ & $1.93 \pm 0.06$ & $4.61 \pm 0.08$ & $6.24 \pm 0.06$ \\
\hline So & $3.85 \pm 0.04$ & $3.98 \pm 0.04$ & $3.88 \pm 0.04$ & $4.09 \pm 0.04$ & $3.49 \pm 0.04$ \\
\hline $\mathbf{S m}$ & $1.40=0.37$ & $1.45 \approx 0.38$ & $1.46 \pm 0.37$ & $1.40=0.38$ & $1.54 \pm 0.40$ \\
\hline Th & $2.40 \pm 0.0 \%$ & $2.8^{n} \pm 0.06$ & $2.93 \pm 0.06$ & $3.06 \pm 0.06$ & $3.05 \pm 0.07$ \\
\hline $\mathbf{T i}$ & $1030 \pm 70$ & $1070 \pm 80$ & $1030 \pm 80$ & $1010 \pm 70$ & $1160 \pm 80$ \\
\hline V & $35.0+1.6$ & $40.4 \pm 1.8$ & $38.9 \pm 1.7$ & $38.1 \pm 1.7$ & $38.0 \pm 1.7$ \\
\hline$w$ & $0.7 n 9 \pm 0.182$ & $0.563 \pm 0.150$ & $0.716 \pm 0.209$ & $0.548 \pm 0.208$ & $0.462 \pm 0.198$ \\
\hline
\end{tabular}

nondispersive $x$-ray fluorescence techniques used at eleven different laboratories was recently carried out. 9 Standard samples were prepared by Columbia Sclentific Industries. The INAA program at LLL and the radioactive, source-excited, nondispersive $x$-ray fluorescence technique used at LLI were included. Our results, compared with those reported by ather investigators, are shown in line 4 of Table $\mathrm{J}$.
Each set of data reported in Table 17 consisted of our dried solution deposits and two blanks. The filter substrates were Whatnan 41 and Millipore SMWP filters. The eight elements deposited on each sample were $\mathrm{Al}, \mathrm{K}, \mathrm{V}, \mathrm{Mn}, \mathrm{Fe}, \mathrm{Cu}$, $\mathrm{As}$, and $\mathrm{Pb}$ in amoun ranging from $1.7 \mu \mathrm{g} / \mathrm{cm}^{2}$ to $54 \mu \mathrm{g} / \mathrm{cm}^{2}$. All investigators received separate sets of standards. LLL used the same set for $x$-ray analysis prior to JNAA. 
Table 14. LLL resulte for NBS'EPA standard ny ash (SlaM-I633) drone by INAA.

\begin{tabular}{|c|c|c|c|c|c|}
\hline & $\frac{\text { Replicate I }}{\text { (ppm) }}$ & $\frac{\text { heplicate } 2}{\text { (ppm) }}$ & $\frac{\text { Replicute } 3}{(\text { ppm }}$ & $\frac{\text { Replicatc } 4}{\mid \text { ppm }}$ & $\frac{\text { Heplicale 5 }}{\text { (ppm) }}$ \\
\hline $\mathbf{A l}$ & $125000 \pm 3000$ & $126000 \leq 3000$ & $121000 \pm 2900$ & $118000 \pm 2800$ & $124000 \div 3000$ \\
\hline As & $51.4 \pm 3.0$ & $53.3 \pm 4.1$ & $52.3 \pm 3.0$ & $52.0 \pm 3.9$ & $49.4 \pm 3.7$ \\
\hline $\mathbf{B a}$ & $2700 \pm 160$ & $2590 \pm 180$ & $2680 \pm 180$ & $2610 \neq 180$ & $2480 \neq 170$ \\
\hline$C a$ & $45600 \pm 2700$ & $45500 \pm 2800$ & $\$ 3500 \pm 2700$ & $46260 \pm 2900$ & $\$ 3300=2800$ \\
\hline $\mathrm{Ce}$ & $136.1 \pm 1.7$ & $140.4 \pm 1.8$ & $132.5 \pm 1.7$ & $131.5 \pm 1.7$ & $133.7 \pm 1.7$ \\
\hline $\mathrm{Co}$ & $\$ 3.0 \pm 0.5$ & $43.1 \pm 0.5$ & $41.5 \pm 0.5$ & $41.4 \pm 0.5$ & $41.1 \pm 0.5$ \\
\hline Ch & $129.3 \pm 1.7$ & $132.5 \pm 1.7$ & $121.3 \times 1.6$ & $121.0 \pm 1.0$ & $125,6 \pm 1.7$ \\
\hline $\mathbf{E u}_{\mathbf{u}}$ & $2.36 \pm 0.05$ & $2.29 \pm 0.05$ & $2.17 \pm 0.05$ & $2.14 \pm 0.05$ & $2.15 \pm 0.05$ \\
\hline Fe & $59600 \pm 1200$ & $59600 \pm 1200$ & $56800 \pm 1200$ & $57100 \pm 1200$ & $56700 \pm 1100$ \\
\hline Hf & $6.03 \pm 1.05$ & $5.91 \pm 1.02$ & $5.65 \pm 0.98$ & $5.56 \pm 0.97$ & $5.80 \pm: .01$ \\
\hline In & $0.380 \pm 0.048$ & $0,346 \pm 0,047$ & $0.315 * u .044$ & $0.326=0.043$ & $0.239 \pm 0.043$ \\
\hline K & $13800 \pm 1500$ & $14200 \pm 1200$ & $13700 \pm 1200$ & $14100 \pm 1200$ & $13400 \pm 1900$ \\
\hline La & $67.5 \pm 4.9$ & $68.4 \pm 4.9$ & $64.9 \neq 4.8$ & $64.0 \pm 4.7$ & $60.0 \pm 4.3$ \\
\hline Mn & $520 \pm 14$ & $515 \pm 14$ & $494 \pm 13$ & $496 \pm 13$ & $506 \pm 14$ \\
\hline $\mathrm{Na}$ & $2800 \pm 110$ & $2880 \pm 110$ & $2860 \pm 110$ & $2620 \pm 100$ & $2840 \pm 110$ \\
\hline $\mathbf{S b}$ & $6.49 \pm 0.16$ & $6.63 \pm 0.16$ & $0.40 \pm 0,16$ & $6.09 \pm 0.20$ & $6.32 \pm 0.16$ \\
\hline Sc & $28.8 \pm 0.3$ & $29.0=0.3$ & $27.5 \pm 0.3$ & $27.3 \pm 0.3$ & $27.2 \pm 0.3$ \\
\hline Sm & $11.2 \pm 2.8$ & $11.4 \pm 2.9$ & $11.2 \pm 2.9$ & $11.1 \pm 2.8$ & $10.5 \pm 2.6$ \\
\hline Th & $24.1 \pm 0.4$ & $24.0 \pm 0.4$ & $23.0 \pm 0.4$ & $22.8 \pm 0.4$ & $22.8 \pm 0.4$ \\
\hline $\mathbf{T i}$ & $7590 \pm 640$ & $6950 \pm 600$ & $7100 \pm 600$ & $6880 \pm 590$ & $7550 \pm 620$ \\
\hline $\mathrm{v}$ & $261 \pm 14$ & $243 \pm 12$ & $231 \pm 12$ & $236 \pm 12$ & $250+13$ \\
\hline $\mathbf{w}$ & $4,09=1.14$ & $3.05 \pm 0.93$ & $4.22 \pm 0.91$ & $3.16 \pm 1.23$ & $3.25 \pm 0.86$ \\
\hline
\end{tabular}

The gravimetric standard solutions deposited on Whatman 41 are referred to 26 " $A$ " and " $C$." The values shown for each element in Table 17 are ratios of Whatman 41 and Mulipore fllter averages to the amouni of gravimetric atandard solution deposited, Each participant knew only which elements wore deposited, not how much. The numbers in parenthoses are the standard deviations reported by the various particlpants.
Intercomparlson Within the ACHeX Program

INAA and XRFA Comparisons

A number of Impactors and filters were subjected to analysis by both INAA at LLL and XRF at LBL, ${ }^{10}$ Table 18 lists a series of high-volume specimens showing comparisons for the four elements which were determined by both techniques, These are $\mathrm{Ca}, \mathrm{Tl}, \mathrm{Mn}$ and Br. It will be noted that two determinations 


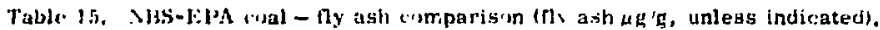

\begin{tabular}{|c|c|c|c|c|c|c|}
\hline & U. of Md. & $N B S^{0}$ & $\begin{array}{l}\text { Hattelle } \\
\text { N.W. }\end{array}$ & Livermore & $\begin{array}{l}\text { Washington } \\
\text { State }\end{array}$ & Oak Ridge \\
\hline $\mathrm{Na}$ & $0.34 \sigma_{c}=0.03 \sigma_{0}$ & & $0.37 x_{1} \pm 0.02 \%$ & $0.28 \% \pm 0.02 \%$ & & $0.34 \%$ \\
\hline $\mathbf{k}$ & & & & $1.38 \% \pm 0.06 \%$ & & $2.54 \%$ \\
\hline$C_{a}$ & $+.2^{\circ} \div \geq 0.5^{\mathrm{n}}$ & & & $4.48 \% \pm 0.2 f \%$ & & $2,94 \%$ \\
\hline Ba & $0.27^{\circ} \pm 0.03^{x}$ & & $10.34 \pm 0.04$ & $0.26^{\circ x} \pm 0.02^{m}$ & & $0.276^{\circ}$ \\
\hline Al & $15.8^{0 \%}=1.2 \tau$ & & $12.6 m_{b} \pm 0.4 \tau_{c}$ & $12.3 \pi \neq 0.6 \%$ & & $B .74 \%$ \\
\hline sc & $2 t=1.5$ & & $27+1.0$ & $28.0 \pm 1.7$ & & 35.1 \\
\hline $\mathbf{T i}$ & $0.73^{*}=0.04 \%$ & & $0.76 \pm 0.0$ & $0.72 \pm 0.07$ & & $0.5 \mathrm{B8} \%$ \\
\hline$v$ & $251: 26$ & $314=8$ & $220 \pm 15$ & $244 \pm 24$ & $223.6 \pm 12.3$ & 170 \\
\hline $\mathrm{Cr}$ & $130+5$ & $131=2$ & $131 \pm 8$ & $120 \div 10$ & $126.2 \pm 4.3$ & \\
\hline Mn & $509=15$ & $493 \pm 7$ & $489 \pm 11$ & $506 \pm 23$ & $480 \times 10.1$ & 441 \\
\hline $\mathrm{Fe}$ & $0.2 \%+n .3 \%$ & & $6.51 \% \pm 0.31 \%$ & $5,8 \% \pm 0,3 \%_{t}$ & & \\
\hline co & $+1.2 \pm 1.0$ & $38^{\mathrm{b}}$ & $40 \pm 2$ & $42+1.9$ & & \\
\hline Ass & $5: .6 \pm 1,0$ & $61 \pm b$ & & $51.7 \pm 5.3$ & $78.7 \pm 3.6$ & \\
\hline Sb & $7.6 \div 1.5$ & & $7.2 \pm 0.8$ & $6.38 \pm 0.41$ & & $7,84 \pm$ \\
\hline In & & & & $0.32 \pm 0.10$ & & \\
\hline ftr & $7.9 \pm 0.6$ & & $8,2 \pm 0.8$ & $5.79 \pm 0.38$ & & \\
\hline $1 \mathbf{a}$ & $1.64=0.12$ & & $3.5 \pm 0.3$ & & & \\
\hline$w$ & & & & $3.5 \pm 1.1$ & & \\
\hline L.a & $82 \pm 5$ & & $82 \pm 4$ & $65.0 \pm 6.6$ & & 82.1 \\
\hline ' 'e & $156 \pm 12$ & & & $135 \pm 7$ & & \\
\hline $\mathrm{Sm}$ & $13.8 \pm 0.6$ & & $12.4 \pm 0.5$ & $11.1 \pm 0.7$ & & \\
\hline Eu & $2.9 \pm 0.2$ & & $2,3 \pm 0.3$ & $2.22 \pm 0.20$ & & \\
\hline$T h$ & $23.5 \pm 2.0$ & $24^{b}$ & $26.2 \pm 1.3$ & $23,3 \pm 1.3$ & & \\
\hline
\end{tabular}

Probable certified value unleas otherwhe indicated.

binformational value only.

were done using $x$-ray fluorescence. These took place before and after neutron activation. In most cases, the second measurement shows a reduction in the amount of each element. Comparing the first XRFA with NAA results, both $B r$ and Mn displayed about $15 \%$ (on the average) higher value by XRFA. A difference in $\mathbf{B r}$ values might be ascribed to volatile logs while that for $\mathrm{Mn}$ might reasonably relate to other causes (e.g., mechanical loss). The reanalysis by XRFA ytelded values for $\mathrm{Mn}$ and $\mathrm{Br}$ which generally agreed better with the NAA results. Comparing the first and second XRFA, the values for the soil-related elements $\mathrm{Ca}$ and $\mathrm{Mn}$ were typically 20\% to $30 \%$ lower for the second analysis.

This discrepancy can be attributed to handling problems whlch caused loss of larger particlea. This seems to be a reasonable abaumption since the specimens are subjented to many shocks both during shipment to Livermore and back to Berkeley 
Table 16. NBS-EPA coal - hy ash comparison (coal $\mu$ q/g, unless indicated).

\begin{tabular}{|c|c|c|c|c|c|c|}
\hline & C. of Md. & NBS $^{a}$ & $\begin{array}{c}\text { Battelle } \\
\text { N. W. }\end{array}$ & Livermore & $\begin{array}{l}\text { Washingtnn } \\
\text { State }\end{array}$ & Oak IRidge \\
\hline Na & $399 \pm 20$ & & $420 \pm 30$ & $313 \pm 22$ & & 470 \\
\hline $\mathbf{K}$ & & & & $0.23 \pm 0.01$ & & $0.38 \mathrm{i}^{\prime \prime}$ \\
\hline $\mathrm{Ca}$ & $0,41 \sigma_{i} \pm 0,05^{r}$ & & & $0.42^{\omega} \pm 0.07 \%$ & & $0.26 \mathrm{~B}^{\prime \prime \prime}$ \\
\hline $\mathrm{Ba}$ & $330=30$ & & & $327+19$ & & 317 \\
\hline $\mathrm{Cl}$ & $970 \pm 110$ & & $800 \pm 200$ & $758 \pm 62$ & & 652.6 \\
\hline $\mathrm{Br}$ & -20 & & & $18.6 \neq 2.4$ & & 16.0 \\
\hline Al & $1,78_{r}^{m} \pm 0,16^{\prime \prime}$ & & $1.78^{\circ} \pm 0.08_{i}^{*}$ & $2.0^{\circ} 0^{\circ} \pm 0.1^{\circ}$ & & $1.23 u_{n}$ \\
\hline Se & $3,20 \pm 0.25$ & & $3.4 \pm 0.3$ & $3,94 \pm 0.19$ & & 6.06 \\
\hline $\mathbf{T} \mathbf{i}$ & $960 \pm 100$ & & $1110 \pm 200$ & $1060 \pm 120$ & & 789 \\
\hline$r$ & $37,0 \pm 3.3$ & $35 \pm 3$ & $33.0 \pm 4$ & $38.3 \pm 3.3$ & $36 \pm 3.8$ & 26.4 \\
\hline $\mathrm{Cr}$ & $15.7 \pm 1.0$ & $20.2 \pm 0.5$ & $19 \pm 2$ & $19.3 \pm 0.97$ & $21.25 \pm 0.43$ & \\
\hline$M \mathbf{n}$ & $45.2 \pm 3.2$ & $40 \pm 3$ & $41 \pm 6$ & $47.6 \pm 3.4$ & & 38.6 \\
\hline Fe & $0,86 \% \pm 0.06 \%$ & $0.87 \sigma_{i} \pm 0.03 \sigma_{i}$ & $0.81 \sigma_{n} \pm 0.07 r_{n}$ & $0.82 w_{n} \pm 0.04 " n$ & & \\
\hline $\mathrm{Cr}$ & $5.6 \pm 0.3$ & $6^{b}$ & $5.2 \pm 0.4$ & $6.4 \pm 0.28$ & & \\
\hline $2 n$ & -30 & $37 \pm 4$ & $37 \pm 4$ & & & \\
\hline As & $3.7 \pm 0.5$ & $5.9 \pm 0.6$ & & $5,04 \pm 0,66$ & $11.23 \pm 0.93$ & \\
\hline Sb & $4,3 \pm 3.0$ & & $3.7 \pm 2.0$ & $4.1 \pm 5.3$ & & 4.4 \\
\hline In & & & & $0.20 \pm 0.12$ & & \\
\hline Hf & $0.95 \pm 0.0 \mathrm{H}$ & & $0,07 \pm 0,1$ & $0.72 \pm 0.06$ & & \\
\hline$w$ & & & & $0.62 \pm 0.27$ & & \\
\hline $1 . \mathrm{a}$ & $11.3 \pm 0.6$ & & $10.5 \pm 0.5$ & $9.1 \pm 0.3 \mathrm{~B}$ & & 12.8 \\
\hline Ce & $20.4 \pm 1.5$ & & & $18,5 \neq 0,65$ & & \\
\hline $\mathbf{s m}$ & $1.83 \pm 0.00$ & & $1.7+0.3$ & $1.48 \pm 0.07$ & & \\
\hline Eu & $0.3 B \pm 0.03$ & & $0.28 \pm 0.01$ & $0.32 \pm 0.01$ & & \\
\hline Th & $3,0 \pm 0,3$ & $3.0^{b}$ & $3.45 \pm 0.18$ & $2,97 \pm 0,17$ & & \\
\hline $\mathrm{U}$ & & & & & & 1.26 \\
\hline
\end{tabular}

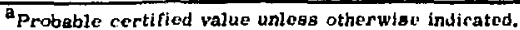

binformational value only.

and during the irradiation process which involves the use of a pneumatic sample transport systera into and out of the reactor.

Table 19 showa comparison of the same four elements on Impactors and total and after fluters.

Analysin of Aluminum by INAA and fiomic abooption fmayer (AAS)

During ACHEX-I, an unresolved discrepancy was discovered for the analysis of AI by INAA and AAS. The aerosol samples were collected on high-volume Whatman 41 air filters, A.AS analyses were done at AIHL on 100-130 $\mathrm{cm}^{2}$ of the filter and consisted of $\mathrm{LLBO}_{2}$ fusion, dissolution and aspiration. The average NAA/AAS ratio for the 23 fliters is 0.638 , The individual values have a correlation factor of 0.85 which uggeats a systematic difference between the two procedures. 
Tabic 17. Firgt XIRl'A intercomparison study - ratio of $A$ and (' averages to gravimetric stanclarda.

\begin{tabular}{|c|c|c|c|c|c|c|c|c|c|}
\hline 3.1 & $\begin{array}{c}\text { simpla } \\
\text { Ivpi }\end{array}$ & 31 & h & 1 & MIr & $\therefore$ & t & 4 . & $1+k_{1}$ \\
\hline \multirow[t]{2}{*}{ ! } & $A$ & & $1.11+111.21$ & 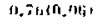 & 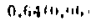 & $(1 . \div+1.201$ & $1+.53+1+.1 \cdot$ & $11 . .81811,01 \% 1$ & : : \\
\hline & $r^{\prime}$ & & 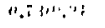 & a $5,3614 . \ln 1$ & 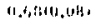 & $11.4 \times 1+1111$ & 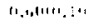 & 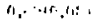 & $0,7+(0), 0 \%$ \\
\hline \multirow[t]{2}{*}{2} & $\mathbf{A}$ & 1.7. & $11 .:$ & $(1,7)$ & 0,75 & n.45i & 1.:-1" & $\because, 4 !$ & 0.610 \\
\hline & $s$ & & 1. 1 & יi: & 1.98 & 0.74 & a.ib & $1 "+:$ & $" . C_{1}$ \\
\hline \multirow[t]{2}{*}{; } & $A$ & & $15 .+1+2+14,11:$ & 1, , :11, & 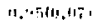 & $0.01+16.0194$ & $1+, 211,1+4$ & 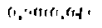 & $11.4(4),+13$ \\
\hline & s. & & $11 .+111 .+1,$. & $\cdot 1+1+1+.111 .1$ & $11,112(11.04$, & $0,3^{2}+11,114$ & ". . tri!.'s" & $17 . \cdots+11.031$ & 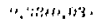 \\
\hline 1.1.1. & $A$ & $11,7 \cdot \mid 11,110\}$ & & 11. $:(1,+)$, & $0.5+210.021$ & $0.5+4 \cdots+1)$ & $(2,: 3 \cdot(1), 1(1)$ & & \\
\hline ISAI & 6 & $11.7 \cdot 611.681$ & & "I. $k+(1+1)+$ & $\left.0.46(0.1)_{2}\right)$ & D. & $1.20(1 . . ! n)$ & & \\
\hline \multirow[t]{2}{*}{5} & A & & $0,132(1,0) 2$ & $i, 1,111,021$ & $0.40+10.01038$ & $0,4 \cdot 210,(1,2)$ & $1 .(n+m),(n)$ & 0.9410 .031 & $1,0.00 .0131$ \\
\hline & $t^{-}$ & & 0.301016 .094$. & $11.9+2416.013$ & $0,+5(0,03)$ & 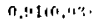 & $0.0+0.0 .1+$ & 0.9410 .031 & $0+2+(0)+13)$ \\
\hline \multirow[t]{2}{*}{ is } & $A$ & 1. : : 101.2011 & 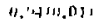 & $11, x \leq 11 ., 11)$ & 1.0110 .021 & $1.010 .+1)$ & $0.0^{1}+1(0.03)$ & $16.7610,517$ & 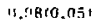 \\
\hline & $r$ & 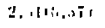 & $1.016,11$, & $1.0+10.111$ & $0,+5(0,(12)$ & $" .1+50(0.011$ & $0.65(0.021$ & $1.2060 .1 \mathrm{~J} 81$ & $0,9200,03 i$ \\
\hline \multirow[t]{2}{*}{7} & $A$ & $1,34,11,121$ & $0.950 .04,1$ & $0.41001,1 \mathrm{H}_{2} \mathrm{O}$ & $1 . \ln (t) . u \hat{r})$ & $1,00(0,05)$ & 0.6210 .04 & 0.8610 .061 & $1.00\{0,05\}$ \\
\hline & $c$ & $1.79011 .11)$ & 1.1500 .071 & 1.12911 .0181 & $1.17(0.08$ & $1.11 ; ; 0.041$ & $1.03: 10.061$ & 0.8910 .051 & 1.010.05 \\
\hline \multirow[t]{2}{*}{8} & $A$ & & 1. netertiti) & $1,0110.151$ & $1.12(0.17)$ & 1.1110 .17 & $0+70.161$ & $1.03(0.15)$ & $0.96(0.15)$ \\
\hline & & & $1,03(0.15)$ & $1,1,-(0,111)$ & $1.02(0.15)$ & $1.0+10.16$ & 1.1100 .171 & 1.1500 .171 & $1,06(0,16)$ \\
\hline \multirow[t]{2}{*}{$\because$} & $A$ & & & $17, P^{2}$ & 0.40 & 0.98 & 1.01 & 5.00 & 1.03 \\
\hline & 6 & & & $1 . \ln i$ & 1.10 & 1.19 & 1.17 & 1.11 & \\
\hline \multirow[t]{2}{*}{10} & $\therefore$ & $1,+1 i(0,2 ; 1$ & $1,21100.111$ & $1.13(0.17)$ & $1.21(0.1 ! 1)$ & $0.93(0.13)$ & 0.7410 .231 & $1.10(0.25)$ & $1.13(0.27)$ \\
\hline & c & $1.70(0.26)$ & $1.25(0.20)$ & $1, ! ! 1(0,14)$ & $1.11(0.18)$ & $0,86(0,12)$ & $0.86(0.10)$ & 1.0510 .243 & $1.09(0.24)$ \\
\hline \multirow[t]{2}{*}{11} & $A$ & 11.71 & $0,42(0.1)+1$ & $1.1(110.06\}$ & $1.03(0.08)$ & $1.01(0.08)$ & $0.38(0,09)$ & $0.93(0,12)$ & 0.8460 .08 \\
\hline & c & $0,5 B$ & $0,1+2(0,015)$ & $1.17(0.0 \%)$ & $1,09(0,08)$ & $1.09(0.08)$ & $0.72(0.07)$ & $1.06(0.17)$ & $0.81(0.09)$ \\
\hline \multirow[t]{2}{*}{12} & $A$ & $1.5(2,1)$ & $1.13(0.14)$ & $0 . \operatorname{sen}(0.07)$ & $1.01(0,09)$ & 1.0110 .111 & $1.01(0.12)$ & $(.08(0.15)$ & $1.04(0.10)$ \\
\hline & $c$ & $5.0(1,3)$ & $1.11+10.151$ & $1,02(0,10)$ & $(.06(0.12)$ & $1.11(0.12)$ & $1.04(0.10)$ & $1.18(0.16)$ & $1.07(0.11)$ \\
\hline
\end{tabular}

The analysis of NBS SRM-1632 and NBS SRM-1633 by INAA showe good agreement with other labaratories, although Al is not certified (see Tables 14 and 15). The first XRFA Intercompartson Study results show a reasonable agreement within errors between INAA and XIFA for Al.

The AAS analysis of NBS certifled standard have shown good accuracy for Al, The results of INAA and AAS analysea of "standards" do not offer any explanation for the discrepancy between the two pro- cedures. A possible source of error for INAA would be loss of large particles either during sample transit or during pneumatic insertion and removal of samples from the reactor. During ACHEX-II, sample handling and procedures were revised to largely ellminate the effects of such particle loss.

\section{EPISODIC DATA}

Figures 3-6 show Q2 spectra taken of stages 1A, 1B, 4 and the after filter, 
Table 18. Comparis on data determined by INAA (LLL.) and XAF (LBL). ${ }^{a}$

\begin{tabular}{|c|c|c|c|c|c|}
\hline Specimen & & $\mathrm{Ca}$ & $\mathbf{T i}$ & $\mathrm{Mn}$ & $\mathrm{Br}$ \\
\hline \multirow[t]{3}{*}{ TA0151HV } & XRF-1 & $1470 \pm 70$ & $210 \pm 42$ & $46 \pm 4$ & $302 \pm 12$ \\
\hline & INAA & {$[329 \pm 450$} & $125 \pm 50$ & $34 \pm 1$ & $259 \pm 9$ \\
\hline & XRF-2 & $1120 \pm 60$ & $124 \pm 36$ & $34 \pm 3$ & $252 \pm 10$ \\
\hline \multirow[t]{3}{*}{ TB0153HV } & XRF-1 & $2060 \pm 100$ & $308 \pm 85$ & $76 \pm 5$ & $749 \pm 30$ \\
\hline & INAA & $2526 \pm 660$ & $326 \pm 81$ & $58 \pm 2$ & $555 \pm 16$ \\
\hline & $X R F-2$ & $1610 \pm 80$ & $226 \pm 67$ & $59 \pm 4$ & $634 \pm 25$ \\
\hline \multirow[t]{3}{*}{ TCO $153 \mathrm{HV}$} & XRF-1 & $2530 \pm 130$ & $328 \pm 106$ & $83 \pm 6$ & $733 \pm 29$ \\
\hline & INAA & $2278 \pm 328$ & $301 \pm 93$ & $64 \pm 2$ & $639 \pm 23$ \\
\hline & XRF-2 & $1930 \pm 100$ & $240 \pm 73$ & $59 \pm 5$ & $642 \pm 26$ \\
\hline \multirow[t]{3}{*}{ TD0154 HV } & XRF-1 & $2110 \pm 110$ & $270 \pm 77$ & $64 \pm 6$ & $568 \pm 28$ \\
\hline & INAA & $1843 \pm 754$ & $251 \pm 92$ & $46 \pm 2$ & $521 \pm 15$ \\
\hline & XRF-2 & $1700 \pm 70$ & $183 \pm 52$ & $42 \pm 6$ & $534 \pm 21$ \\
\hline \multirow[t]{3}{*}{ TE0155HV } & XRF-1 & $1340 \pm 70$ & $209 \pm 28$ & $48 \pm 3$ & $221 \pm 9$ \\
\hline & INAA & $1400 \pm 484$ & $290 \pm 128$ & $34 \pm 1$ & $420 \pm 15$ \\
\hline & XRF-2 & $984 \pm 49$ & $123 \pm 32$ & $33 \pm 3$ & $407 \pm 16$ \\
\hline \multirow[t]{3}{*}{ UF0156HV } & XRF-1 & $1890 \pm 90$ & $275 \pm 61$ & $71 \pm 4$ & $473 \pm 19$ \\
\hline & INAA & $2249 \pm 247$ & $297 \pm 67$ & $59 \pm 2$ & $433 \pm 16$ \\
\hline & XRF-2 & $1560 \pm 80$ & $193 \pm 53$ & $58 \pm 4$ & $432 \pm 17$ \\
\hline \multirow[t]{3}{*}{ VH0158HV } & XRF-1 & $3780 \pm 190$ & $289 \pm 43$ & $92 \pm 4$ & $289 \pm 12$ \\
\hline & INAA & $4764 \pm 369$ & $219 \pm 63$ & $80 \pm 3$ & $217 \pm 6$ \\
\hline & XRF-2 & $3240 \pm 160$ & $192 \pm 44$ & $80 \pm 4$ & $257 \pm 10$ \\
\hline \multirow[t]{3}{*}{ V10159HV } & XRF-1 & $3730 \pm 190$ & $300 \pm 42$ & $89 \pm 4$ & $312 \pm 12$ \\
\hline & IN $A A$ & $4705 \pm 376$ & $355 \pm 65$ & $74 \pm 2$ & $260 \pm 9$ \\
\hline & XRF-2 & $2980 \pm 150$ & $194 \pm 50$ & $72+4$ & $269 \pm 11$ \\
\hline \multirow[t]{3}{*}{$\mathrm{VJ} 0160 \mathrm{HV}$} & XRF-1 & $3150 \pm 160$ & $384: 26$ & $86 \pm 5$ & $162 \pm 6$ \\
\hline & INAA & $2706 \pm 321$ & $265 \pm 64$ & & $131 \pm 4$ \\
\hline & XRF-2 & $1810 \pm 90$ & $185 \pm 2 B$ & $42 \pm 4$ & $130 \pm 5$ \\
\hline \multirow[t]{3}{*}{ WK0161HV } & XRF-1 & $1280 \pm 60$ & $152 \pm 85$ & $42 \pm 3$ & $251 \pm 10$ \\
\hline & INAA & $1308 \pm 7:$ & $181 \pm 56$ & $40 \pm 1$ & $203 \pm 6$ \\
\hline & XRF-Z & $1120 \pm 60$ & $114 \pm 81$ & $37 \pm 3$ & $223 \pm 9$ \\
\hline \multirow[t]{3}{*}{ WL0163HV } & XRF-1 & $1450 \pm 70$ & $199 \pm 44$ & $54 \pm 4$ & $1190 \pm 50$ \\
\hline & INAA & $1936 \pm 60$ & $<14 \mathrm{~B}$ & $44 \pm 2$ & $1212 \pm 34$ \\
\hline & XRF-2 & $1100 \pm 60$ & $125 \pm 51$ & $40 \pm 3$ & $1140 \pm 50$ \\
\hline
\end{tabular}

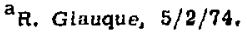


Table 19. Comparison of data determined by INAA (LLL) and XRF (LBL). ${ }^{a}$

\begin{tabular}{|c|c|c|c|c|c|}
\hline Specimen & & $\mathrm{Ca}$ & $\mathrm{Ti}$ & $\mathrm{Mn}$ & $\mathrm{Br}$ \\
\hline \multirow[t]{2}{*}{ TBO260SAL } & $X R F-1$ & $395 \pm 60$ & $73 \pm 7$ & $5 \pm 2$ & $16 \pm 1$ \\
\hline & INAA & $743 \pm 189$ & $158 \pm 43$ & $23.7 \pm 1$ & $16.8 \pm 0.5$ \\
\hline \multirow[t]{2}{*}{ TB0261SBI } & XRF-1 & $\leq 60$ & $6 \pm 5$ & $\leq 6$ & $11 \pm 1$ \\
\hline & INAA & $119 \pm 70$ & $35 \pm 9$ & $4.4 \pm 0.43$ & $12.2 \pm 0.36$ \\
\hline \multirow[t]{2}{*}{ TB0262S2L } & XRF-1 & $204 \pm 57$ & $17 \pm 6$ & $3 \pm 2$ & $21 \pm 1$ \\
\hline & INAA & $177 \pm 81$ & $46 \pm 126$ & $8.7 \pm 0.59$ & $22.4 \pm 0.65$ \\
\hline \multirow[t]{2}{*}{ ТВ026353I } & XRF-1 & $325 \pm 59$ & $29 \pm 6$ & $4 \pm 2$ & $53 \pm 2$ \\
\hline & INAA & $313 \pm 87$ & $51 \pm 11$ & $7.1 \pm 0.6$ & $43 \pm 1.2$ \\
\hline \multirow[t]{2}{*}{ TB026454I } & $\mathrm{XRF}-1$ & $=100$ & $\leq 15$ & $\leq 7$ & $107 \pm 4$ \\
\hline & INAA & $15.5 \pm 56$ & $16.1 \pm 8.7$ & $4.4 \pm 0.4$ & $90 \pm 2.5$ \\
\hline \multirow[t]{2}{*}{ TB0766AFL } & $X R F^{*}-1$ & $166 \pm 30$ & $\leq 40$ & $9 \pm 5$ & $488 \pm 20$ \\
\hline & INAA & $225.6 \pm 264.5$ & $\leq 52.2$ & $15.3 \pm 1.3$ & $417.4 \pm 11.3$ \\
\hline \multirow[t]{2}{*}{ TBO51GTF } & $X R F-1$ & $2090 \pm 80$ & $392 \pm 98$ & $93 \pm 7$ & $735 \pm 29$ \\
\hline & INAA & $1700 \pm 800$ & $455 \pm 244$ & $53 \pm 2.4$ & $67^{\circ}+19$ \\
\hline \multirow[t]{2}{*}{ UC0300SAL } & $\mathrm{XRF}-1$ & $589 \pm 30$ & $149 \pm 24$ & $18 \pm 3$ & $16 \pm 2$ \\
\hline & INAA & $405 \pm 372$ & $138 \pm 39$ & $13.7 \pm 0.8$ & $13.6 \neq 0.4$ \\
\hline \multirow[t]{2}{*}{ LF0301SBL } & $X R F-1$ & $93 \pm 15$ & $2 B \pm 5$ & $5 \pm 2$ & $8 \pm 2$ \\
\hline & INAA & $\leq 7.6$ & $23 \pm 7$ & $2.5 \pm 0.35$ & $8.1 \pm 0.25$ \\
\hline \multirow[t]{2}{*}{ UF0302S2I } & XRF-1 & $172 \pm 17$ & $26 \pm 5$ & $7 \pm 3$ & $20 \pm 2$ \\
\hline & INAA & $267 \pm 171$ & $42 \pm 10$ & $5.2 \pm 0.4$ & $19.1 \pm 0.6$ \\
\hline \multirow[t]{2}{*}{ UT0303S3L } & $x R F-1$ & $214 \pm 17$ & $40 \pm 17$ & $10 \pm 3$ & $51 \pm 2$ \\
\hline & INAA & $367 \pm 87$ & $22.1 \pm 10$ & $10.2 \pm 0.63$ & $45 \pm 1.3$ \\
\hline \multirow[t]{2}{*}{ Lifo30^S4L } & XRl- 1 & $58 \pm 15$ & $\leq 18$ & $5 \pm 3$ & $140 \pm 6$ \\
\hline & INAA & $45 \pm 117$ & $\leq 23.6$ & $6.6 \pm 0.5$ & $114 \pm 3$ \\
\hline \multirow[t]{2}{*}{ UF0813AFL } & $\mathrm{XRF-1}$ & $35 \pm 29$ & $\leq 35$ & $20 \pm 5$ & $272 \pm 11$ \\
\hline & INAA & $99.3 \pm 139$ & $\leq 44$ & $12.6 \pm 1.2$ & $231 \pm 6.6$ \\
\hline \multirow[t]{2}{*}{ UF0670TF } & $\mathbf{X} R F-1$ & $2110 \pm 80$ & $995 \pm 94$ & $84 \pm 7$ & $507 \pm 20$ \\
\hline & INAA & $1890 \neq 1636$ & $392 \pm 98$ & $58 \pm 2.5$ & $456 \pm 13$ \\
\hline \multirow[t]{2}{*}{ VHO340SAL } & $\mathrm{XRF}=1$ & $584 \pm 29$ & $73 \pm 6$ & $14 \pm 3$ & $8 \pm 2$ \\
\hline & INAA & $1098 \pm 179$ & $136 \pm 33$ & $21 \neq 1$ & $6.3 \pm 0.2$ \\
\hline \multirow[t]{2}{*}{ VH034ISBL } & XFF-1 & $241 \pm 17$ & $30 \pm 12$ & $5 \pm 2$ & $4 \pm 1$ \\
\hline & INAA & $373 \pm 88$ & $36 \pm 9$ & $10.7 \pm 0.6$ & $3.5 \pm 0.13$ \\
\hline \multirow[t]{2}{*}{ VH0342S2L } & $X \cap F-1$ & $400 \pm 20$ & $44 \pm 17$ & $7 \pm 2$ & $12 \pm 2$ \\
\hline & INAA & $473 \pm 98$ & $55 \pm 12$ & $8.6 \pm 0.6$ & $9.5 \pm 0.3$ \\
\hline \multirow[t]{2}{*}{ VH0343S3L } & XRF-1 & $453 \pm 23$ & $44 \pm 6$ & $8 \pm 3$ & $24 \pm 2$ \\
\hline & INAA & $538 \pm 271$ & $48.6 \pm 12$ & $8,1 \pm 0,6$ & $21 \pm 0.6$ \\
\hline \multirow[t]{2}{*}{ VHC 344S4L } & XRF-1 & $63 \pm 15$ & $\leq 15$ & $\leq 7$ & $59 \pm 2$ \\
\hline & INAA & $275 \pm 156$ & $\leq 17.6$ & $2.7 \pm 0.38$ & $59 \pm 1.7$ \\
\hline
\end{tabular}


Table 19 (continued)

\begin{tabular}{|c|c|c|c|c|c|}
\hline Specimen & & $\mathrm{Ca}$ & $\mathbf{T} \mathbf{i}$ & Mn & $B r$ \\
\hline \multirow[t]{2}{*}{ VHOB53AFL } & XRF-1 & $107 \pm 29$ & $\leq 24$ & $\leq 12$ & $145 \pm 6$ \\
\hline & IXAA & $218 \pm 256$ & $\leq 31$ & $6.6 \pm 1.1$ & $144 \pm 4$ \\
\hline \multirow[t]{2}{*}{ VH07У2TF } & XRF-1 & $3280 \pm 130$ & $340 \pm 39$ & $69 \pm 6$ & $294 \pm 12$ \\
\hline & INAA & $4381 \pm 526$ & $375 \pm 82$ & $55 \pm 2.4$ & $266 \pm 7.5$ \\
\hline \multirow[t]{2}{*}{ V10330SAL } & XRF-1 & $1410 \pm 70$ & $148 \pm 17$ & $28 \pm 3$ & $5 \pm 1$ \\
\hline & INAA & $2537 \pm 68$ & $232 \pm 67.6$ & $33.4 \pm 1.32$ & $5.36 \pm 0.180$ \\
\hline \multirow[t]{2}{*}{ V10331SBL } & XRF-1 & $687 \pm 34$ & $68 \pm 17$ & $9 \pm 3$ & $5 \pm 2$ \\
\hline & INAA & $759.6 \pm 137$ & $98 \pm 24$ & $12 \pm 0.656$ & $5.26 \pm 0.161$ \\
\hline \multirow[t]{2}{*}{ V10332S2L } & $\mathrm{XRF}-11$ & $584 \pm 29$ & $69 \pm 20$ & $13 \pm 2$ & $7 \pm 1$ \\
\hline & INAA & $676 \pm 117.6$ & $84.4 \pm 18.4$ & $11.5 \pm 0.642$ & $7.14 \pm 0.214$ \\
\hline \multirow[t]{2}{*}{ V10333S3L } & XRF-1 & $474 \pm 20$ & $48 \pm 6$ & $8 \pm 2$ & $19 \pm 2$ \\
\hline & INAA & $565 \pm 114.5$ & $42.1 \pm 10.4$ & $8.16 \pm 0.640$ & $21.98 \pm 0.637$ \\
\hline \multirow[t]{2}{*}{ V10334S4L } & XRF-1 & $76 \pm 16$ & $\leq 21$ & $6 \pm 3$ & $107 \pm 4$ \\
\hline & INAA & $270.8 \pm 89$ & $\leq 22.81$ & $3.57 \pm 0.464$ & $101.8 \pm 2.89$ \\
\hline \multirow[t]{2}{*}{ V101125AFL } & XRF-1 & $193 \pm 29$ & $\leq 30$ & $\leq 14$ & $129 \pm 5$ \\
\hline & INAA & $156.1 \pm 140$ & $\leq 31.6$ & $5.34 \pm 1.06$ & $116.1 \pm 3.3$ \\
\hline \multirow[t]{2}{*}{ V10806TF } & XRF-1 & $8830 \pm 440$ & $815 \pm 129$ & $141 \pm 8$ & $294 \pm 5$ \\
\hline & INAA & $7506 \pm 2764$ & $918.2 \pm 202$ & $118.7 \pm 4.1$ & $258 \pm 7.3$ \\
\hline \multirow[t]{2}{*}{ TD0280SAL } & XRF-1 & $619 \pm 71$ & $91 \pm 7$ & $17 \pm 3$ & $15 \pm 1$ \\
\hline & INAA & $663 \pm 155$ & $112 \pm 29$ & $14.5 \pm 0.8$ & $8.5 \pm 0.26$ \\
\hline \multirow[t]{2}{*}{ TD0281SBL } & XRF-1 & $\leq 80$ & $\leq 15$ & $\leq 7$ & $8 \pm 1$ \\
\hline & INAA & $147 \pm 76$ & $18 \pm 7$ & $3.9 \pm 0.4$ & $7.5 \pm 0.23$ \\
\hline \multirow[t]{2}{*}{ TD0282S2L } & $X R F=1$ & $179 \pm 57$ & $18 \pm 6$ & $6 \pm 2$ & $20 \pm 1$ \\
\hline & INAA & $417 \pm 95$ & $59 \pm 12$ & $7.9 \pm 0.6$ & $15.5 \pm 0.46$ \\
\hline \multirow[t]{2}{*}{ TD0283S3L } & XRF-1 & $206 \pm 58$ & $18 \pm 6$ & $\leq 8$ & $38 \pm 2$ \\
\hline & INAA & $299\llcorner 86$ & $42 \pm 11$ & $6.5 \pm 0.6$ & $37 \pm 1$ \\
\hline \multirow[t]{2}{*}{ TD0284S4L } & XRF-1 & $\leq 60$ & $\leq 15$ & $\leq 8$ & $98 \pm 1$ \\
\hline & INAA & $43 \pm 63$ & $18 \pm 0$ & $4.1 \pm 0.43$ & $88 \pm 2.5$ \\
\hline \multirow[t]{2}{*}{ TD0786AFL } & XRF-1 & $111 \pm 27$ & $18 \pm 10$ & $\leq 13$ & $202 \pm 8$ \\
\hline & INAA & $131 \pm 137$ & $<37.2$ & $3.8 \pm 1.0$ & $183 \pm 5.2$ \\
\hline \multirow[t]{2}{*}{ TD0643TE } & XR F-1 & $1310 \pm 50$ & $239 \pm 53$ & $42 \pm 6$ & $393 \pm 16$ \\
\hline & INAA & $1022 \pm 591$ & $154 \pm 41$ & $25,2 \pm 1.8$ & $350 \pm 9.9$ \\
\hline \multirow[t]{2}{*}{ WL.0350SAL } & XRF-1 & $102 \pm 15$ & $15 \pm 11$ & $3 \pm 2$ & $9 \pm 1$ \\
\hline & INAA & $193.6 \pm 380$ & $27,6 \pm 8.7$ & $4,58 \pm 0.926$ & $9.57 \pm 0.292$ \\
\hline \multirow[t]{2}{*}{ WL0351SBL } & SRF-1 & $35 \pm 15$ & $14 \pm 5$ & $\leq 7$ & $8 \pm 1$ \\
\hline & INAA & $118 \pm 114$ & $5.54 \pm 4,80$ & $1.12 \pm 0.75$ & $6.09 \pm 0.109$ \\
\hline \multirow[t]{2}{*}{ WLO352SEL } & XRF-l & $201 \pm 16$ & $14 \pm 10$ & $\leq 7$ & $12 \pm 2$ \\
\hline & INAA & $65.7 \pm 66.9$ & $\leq 14.9$ & $1.9 \pm 0.37$ & $11.9 \pm 0.355$ \\
\hline
\end{tabular}


Table 19 (continued)

\begin{tabular}{|c|c|c|c|c|c|}
\hline Specimen & & $\mathrm{Ca}$ & $T i$ & $\mathrm{Mn}$ & $\mathrm{Br}$ \\
\hline \multirow[t]{2}{*}{ WL0353S3L } & XRF-1 & $114 \pm 16$ & $21 \pm 5$ & $\leq 7$ & $30 \pm 2$ \\
\hline & INAA & $91.6 \pm 76$ & $14.1 \pm 6.77$ & $2.24 \pm 0.388$ & $25.2 \pm 0.729$ \\
\hline \multirow[t]{2}{*}{ WL0354S4L } & $X R F-1$ & $4 ! \pm 15$ & $\leq 15$ & $4 \pm 2$ & $39 \pm 2$ \\
\hline & INAA & $35.3 \pm 63.1$ & $=16$ & $3.07 \pm 0.384$ & $40.0 \pm 1.15$ \\
\hline \multirow[t]{2}{*}{ WL1038AFL } & $X R F-1$ & $84 \pm 29$ & $\leq 31$ & $13 \pm 5$ & $160 \pm 6$ \\
\hline & INAA & $158 \pm 234$ & $\leq 35$ & $6.0 \pm 1.1$ & $123.5 \pm 3.5$ \\
\hline \multirow[t]{2}{*}{ WL_1096TF } & $X R F=1$ & $424 \pm 37$ & $\leq 89$ & $26 \pm 6$ & $220 \pm 9$ \\
\hline & INAA & $569 \pm 273$ & $81.1 \pm 29.8$ & $14.6 \pm 1.4$ & $178 \pm 5.1$ \\
\hline \multirow[t]{2}{*}{ WK0320SAL } & XRF-1 & $188 \pm 16$ & $35 \pm 11$ & $6 \pm 2$ & $7 \pm 1$ \\
\hline & INAA & $201.7 \pm 89.6$ & $80.4 \pm 17.2$ & $\leq 0.0031$ & $5.48 \pm 0.181$ \\
\hline \multirow[t]{2}{*}{ WK0321SBL } & XRF-1 & $28 \pm 15$ & $15 \pm 5$ & $\leq 6$ & $5 \pm 1$ \\
\hline & INAA & $7.17 \pm 62.0$ & $16.5 \pm 5.26$ & $1.85 \pm 0.299$ & $3.24 \pm 0.126$ \\
\hline \multirow[t]{2}{*}{ WK0322S2L } & XRF - 1 & $110 \pm 16$ & $\leq 15$ & $\leq 7$ & $11 \pm 2$ \\
\hline & INAA & 55.9 & $27.0 \pm 6.81$ & $3.78 \neq 0.436$ & $8.63 \pm 0.265$ \\
\hline \multirow[t]{2}{*}{ WK0323S3L } & XRF-1 & $174 \pm 10$ & $20 \pm 8$ & $7 \pm 2$ & $26 \pm 2$ \\
\hline & INAA & $222 \pm 155$ & $22.0 \pm 9.24$ & $4.60 \pm 0.534$ & $23.1 \pm 0.667$ \\
\hline \multirow[t]{2}{*}{ WK0324S4L } & XRF-1 & $65 \pm 16$ & $27 \pm 8$ & $<\mathrm{B}$ & $61 \pm 2$ \\
\hline & INAA & $12.8 \pm 54.1$ & $15,5 \pm 9,698$ & $6.86 \pm 0.508$ & $50.6 \pm 1.43$ \\
\hline \multirow[t]{2}{*}{ WK1 109AFL } & XRF- 1 & $97 \pm 30$ & $27 \pm 11$ & $\leq 14$ & $89 \pm 4$ \\
\hline & INAA & $101 \pm 131$ & $\leq \mathbf{2 9}$ & $2.36 \pm 0.95$ & $70 \pm 2$ \\
\hline \multirow[t]{2}{*}{ WK1084TF } & $\mathbf{X R F}-1$ & $693 \pm 37$ & $123 \pm 30$ & $33 \pm 6$ & $214 \pm 9$ \\
\hline & INAA & $1184 \pm 494$ & $126 \pm 49$ & $26.7: 1.7$ & $154 \pm 4.4$ \\
\hline
\end{tabular}

\footnotetext{
${ }^{a} R$, Glauque, $1 / 25 / 74$.
}

respectively, of a 24-hour Lundgren impactor run at Dominguez Hills, Caltfornia on October 5, 1973 in ACHEX-II. The aerodynamic diameters were $8-15 \mu$ for stage $1,4-8 \mu$ for stage $2,1,5-4 \mu$ for stage $3,0.5-1.5 \mu$ for stage 4 , and $<0.5 \mu$ for stage 5 . The Lundgren impactors used in ACHEX had two stage 1's - that is, stages $1 A$ and $1 B$ had the same size slit6. The Lundgrens were modified thls way in order to completely collect all particles in the 8-15 $\mu$ range where bounce-off problems are aevere. By comparing Figures 3-6, one can see the decrease of $\mathrm{Al}, \mathrm{Ca}, \mathrm{Na}$, and the increase of $\mathrm{Cl}, \mathrm{V}$. and $\mathrm{Br}$ with decreasing particle size. Figure 7 shows a 2 -hr total filter spectrum taken from 10-1200 at Dominguez Hills while the 24-hr impactor run was taking place. Analyses of these types of spectra yield elemental diurnal variations over $24-h r$ wtth 2-hr intervals.

Figures 8-12 illustrate the kind of data produced by INAA and how they are used in the experimental interpretations. The analyses can be divided into two types: diurnal patterns, and particule atze distributions. Figures 8 and 9 shows the 


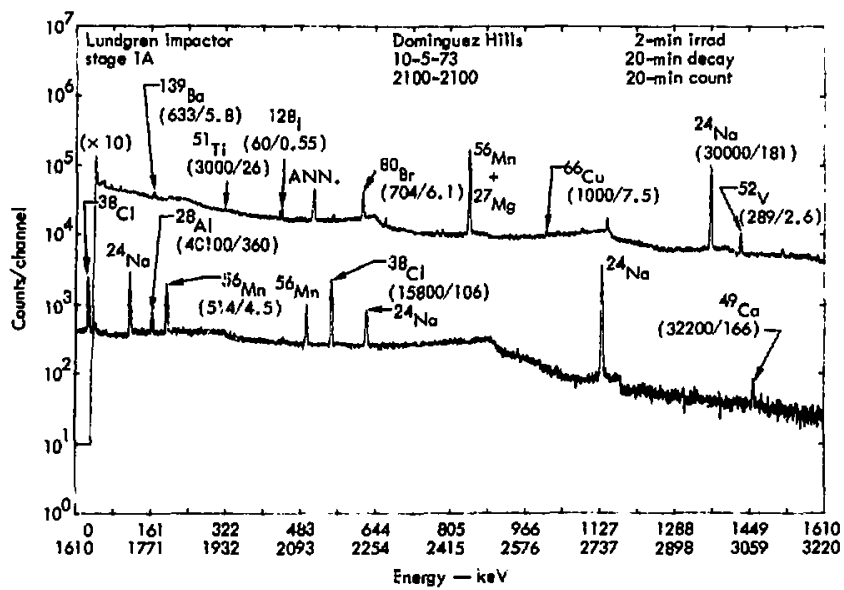

Fig. 3. Gamma-ray spectrum of Dominguez Hills impactor sample collected on 10:5/73 from 2100 to 2100 , stage 1A. Numbers in parentheses indicate (nanograms/nanograms per cubic meter).

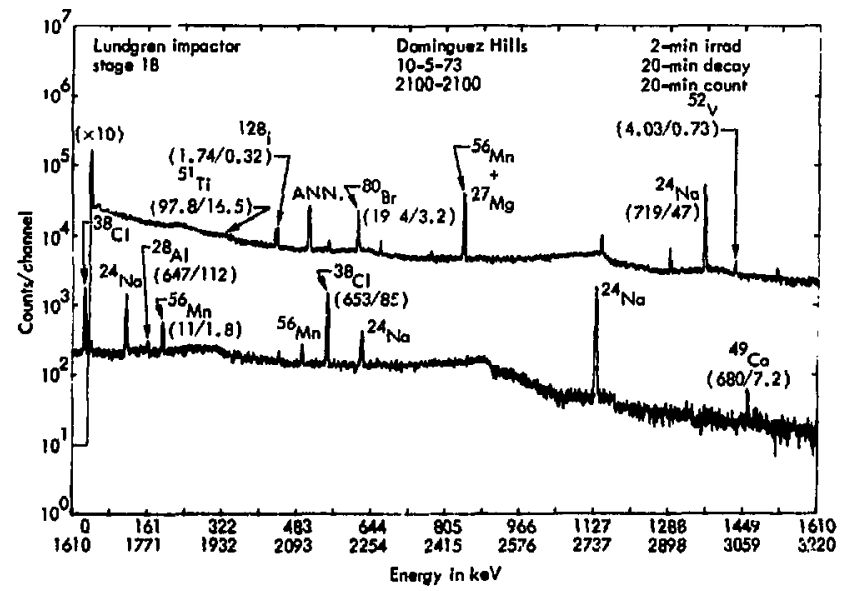

Fig. 4. Gamma-ray spectrum of Dominguez Hills impactor sample collected on $10 / 5 / 73$ from 2100 to 2100 , stage iB. Numbers in parentheses Indicate (nanograme/namograms per cuble meter). 


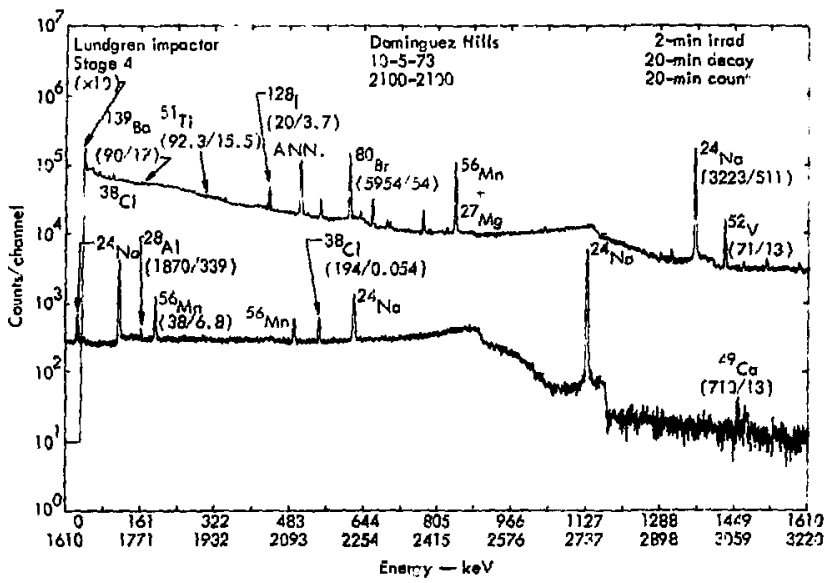

Fig. 5. Ciamma-ruy spectrum of Dominguez Hills impactor sample collected on $10 / 5,73$ from 2100 to 2100 , stage 4, Numbers in parentheses thdicate intmograms, nanograms per cubic meterl.

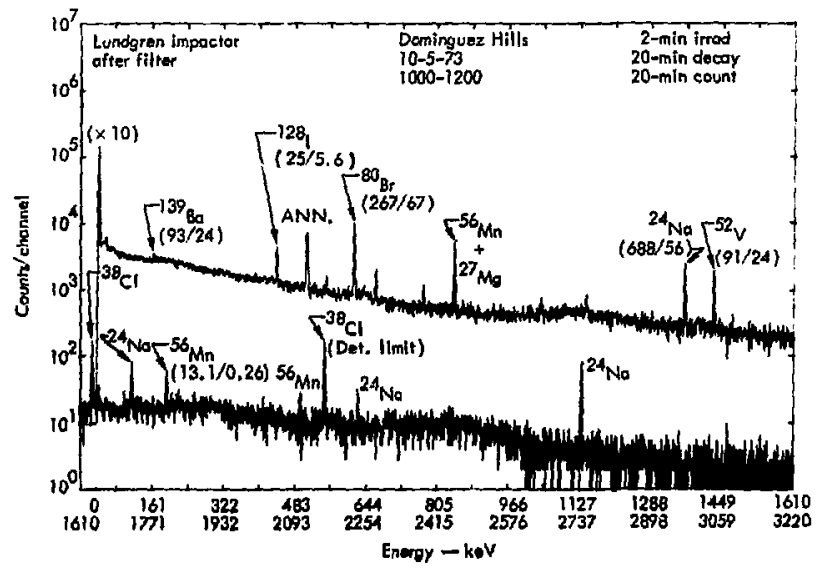

Fig. 6. Gamma-ray spectrum of Domingugz Hills impactor sample collected on $10 / 5 / 73$ from 1000 to 1200 after fltter. Numbers in parentheses indicate \{nanograme/nanograms per cubic meter\}. 


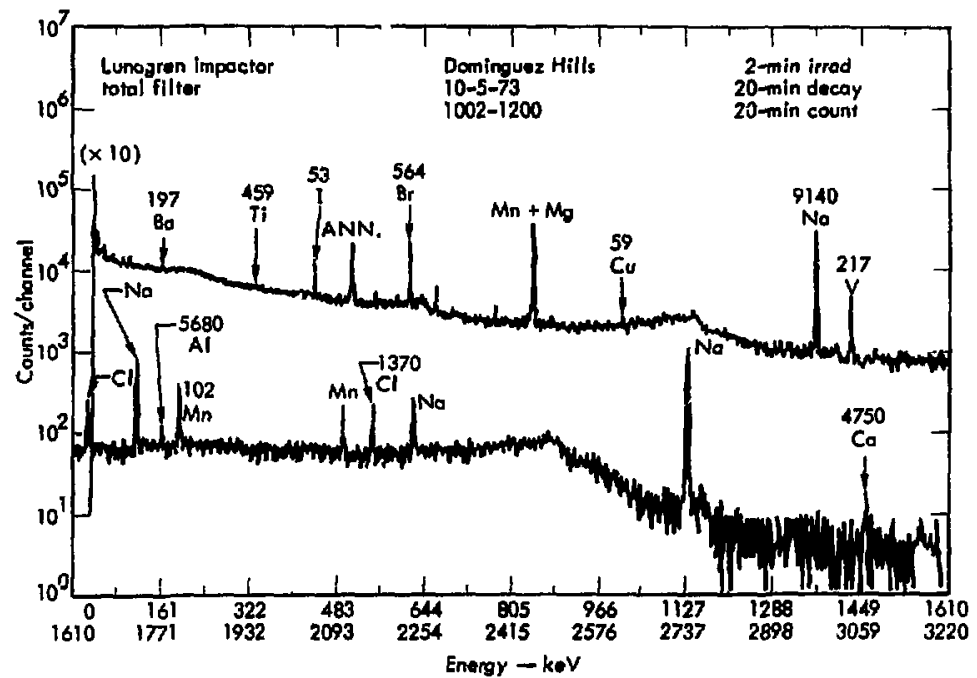

Fig. 7. Gamma-ray spectrum of Dominguez Hills impactor sample collected on $10 / 5 / 73$ from 1000 to 1200 total filter. Numbers indicate total nanograms detected,

Harbor Freeway episode of September 20, 1972. Lundgren impactor substrates were cut into two-hour segments and the Gelman GA-1 after futers were changed every $2 \mathrm{hr}$. Samples were collected one block from the freeway. Figure 8 shows the particle size distributions for $\mathrm{Br}, \mathrm{Na}, \mathrm{Cl}$, and $\mathrm{Al}$ for early morning and late afternoon commuter periods. Figure 9 shows the diurnal patterns of $\mathrm{Pb}, \mathrm{Br}, \mathrm{Na}, \mathrm{Cl}$, A1, $V$, and total mass for the after filters ( $<0.5 \mu$ particles) for the $24-\mathrm{hr}$ period. The $\mathrm{Pb}$ data are taken from Bob Glauque at Lawrence Berkeley Laboratory. 10

Fig, 8. Particle size distribution of $\mathrm{Br}$, CI, Na, AI, collected at Harbor Ereeway, 9/20/73.

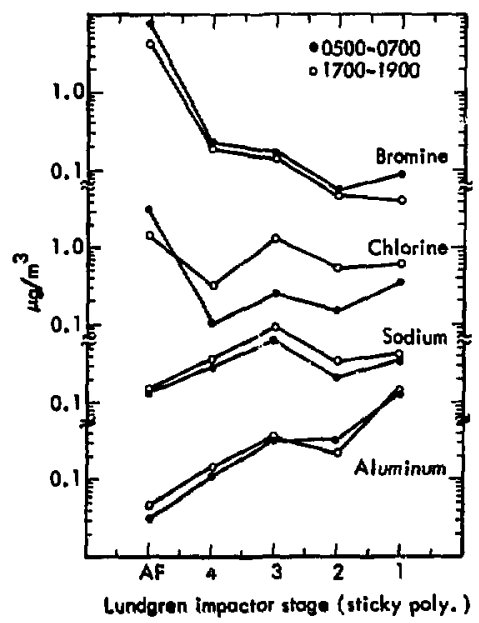


In Figure : the $(1,13 r$, alti 11, diurnat patterns track each ither. Hhenghorut the day, indicating a cummon sulumicren particle souree, namely inarl halder amissions from aut, exhausts. On the there hand $\mathrm{Al}, \mathrm{V}$, and $\mathrm{Na}$ each prortray different diurnal patterns and ditferent shurces.

The Ho alst pitsution in loigure $B$ is peaked en submicron particlles, trpical of an aulo-engine rombutition soures, with

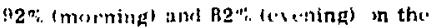
after filcers. The $\mathrm{Ph}$ Br ratios for the after [ilters are 2.1 (morning and 2.0 (avening) which are typica) if frosh axhaust, while the Ifb $13 \mathrm{r}$ ratio in cthyl gasoline is 2 :

Although the CI diurnal pattern is the. same as [or $\mathrm{Br}$, the ( $\mathrm{C}]$ is less romentrated on submirron particles as is Br, the per-

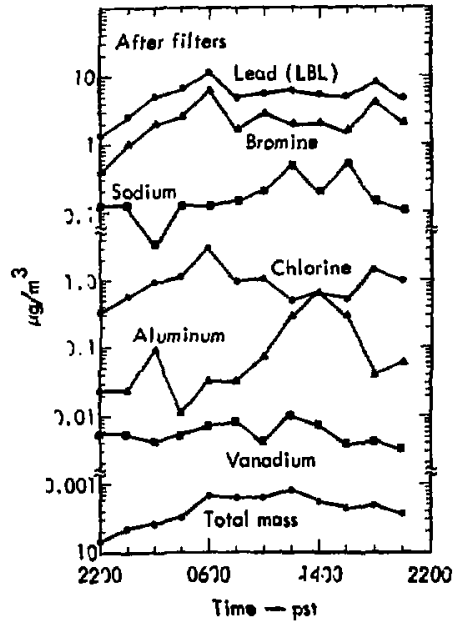

Fig. C. Diurnal patterns of selected elements at Harbor Freeway, $0 / 20 / 73$.

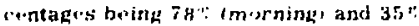
reveningt. The (1) distribution resembles the $\mathrm{Na}$ tistribution in the micron range. it apdxats that most of the submicron (1) is from autr exhaust while most if the swpermieron $\mathrm{Cl}$ is from the marin. arrisol. Stakes 1 -4 show a deficiency or (') relatior t's a se'a water la/c') ratio of 0.55 at $05010-0700(0.5 B(1), 1.4(2), 2.5(3)$. and 2.7411. At 1700201900 , the $\mathrm{Na} / \mathrm{Cl}$ ratio is closer to $0.55(0.72(1), 0.64(2)$, $0.6 .5(3)$, and $1.2(4)\}$. On the after filters the Xa (') ratios are 0.04 (morning) and 0.1 (eveningl. These data are consistent with a Cl iess during the morning hours. pribathly duc th osiclizing agents whict. releasc $\left(\mathrm{Cl}\right.$ to $\mathrm{Cl}_{2}$ gag.

Aluminum show's a predominance of Iarg" particles in Figure 8, typiral of sili-derived aeris is, with only $1.6 \%$ (morning) and $2.2 \%$ (evening) on the after rilter. Sridium is distributed mon a uniformly in the $1-10 \mu$ range. The peaking of the Na distribution on stage $3(1.5-4.0 \mu$ ) is considered tu be repregentative of the marine acersol. Although we du not show is stributituns for $r$, they show r praked on submicron particles, indicating a combustion source.

Figure 10 shows the diurnal patterns of $\mathrm{Na}, \mathrm{Br}, \mathrm{Cl}, \mathrm{A}\}, \mathrm{V}$, and mass on Gelnian CiA- 1 total filters taken in the August 24, 1972 Pasadena episode. Note that $r$ corrolates with total mase, both peaking at 1300 to 1700 . The lia concentration remaing constant, indicating a constant background. In this episode the total $\mathrm{Cl}$ does not follow the total Br or Na. It is not known why $\mathrm{Cl}$ and $\mathrm{il}$ both show a minimum at 1500 to 1700 .

At Fresno Fairgrounds on September 1. 1972, total $\mathrm{Br}$ and $\mathrm{Pb}$ correlate showing a 


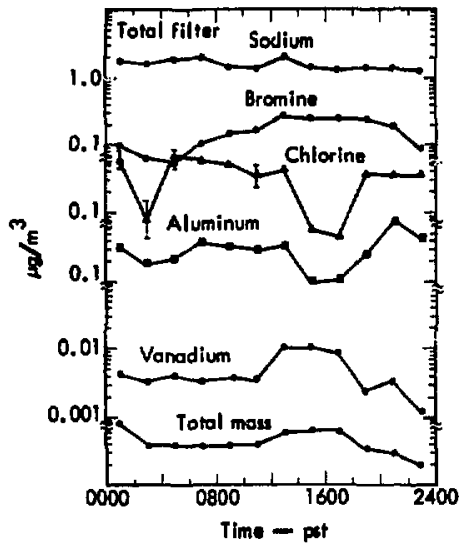

Fig. 10. Diurnal patterns of selected elements at Pasadena, B/24/72.

peak at 0600 . However, Al, Mn, and V. show similar patterns, but unlke $\mathrm{Pb}$ and Br. At Fresno, the particle slze distributions (not shown) show $\mathrm{Na}, \mathrm{V}$, and $\mathrm{Al}$ have substantlal large particle $(8-15 \mu)$ components, Indicating a soll source. Because of Fresno's inland location, we would expect negligible marine $\mathrm{Na}$. The $\mathrm{Cl}$ minimum at 1500 to 1700 is not under stood,

Figure 12 show after-filter diurnal patterns at Pomona on October 24-25, 1972 for submicron $\mathrm{Br}, \mathrm{Pb}, \mathrm{Cl}, \mathrm{Na}$, and Al. Again, as at the prevtous sites discussed, $\mathrm{Br}$ and $\mathrm{Pb}$ correlate, whlle $\mathrm{Al}$ shows a unique dlurnal pattern, Submlcron $\mathrm{Cl}$ does not appear to correlate with $\mathrm{Pb}$ and $B r$ however, it appeara to more closely follow the pattern of $\mathrm{Na}$.

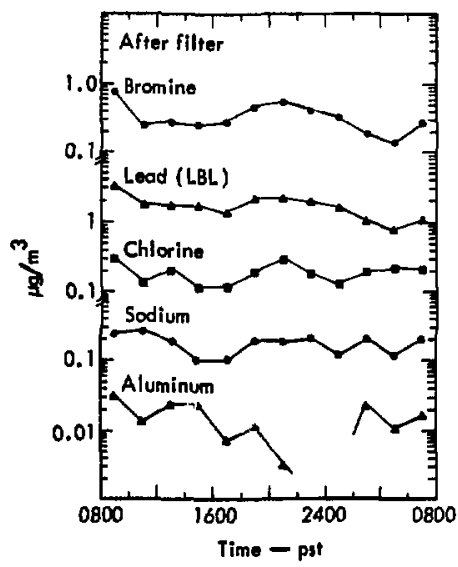

Fig. 11. Diurnal patterns of selected elements at Fresno, 9/1/72.

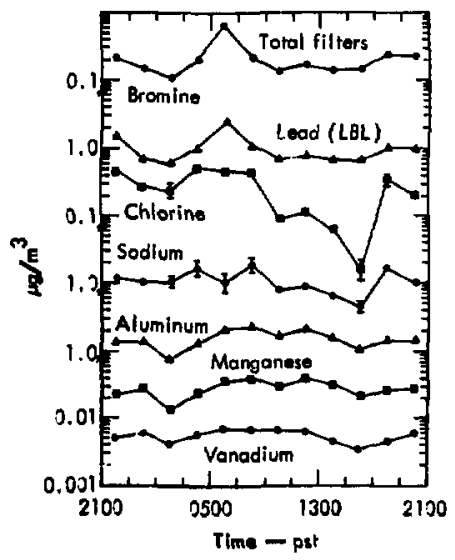

Filg. 12. Diurnal patterns of selected clements at Pomona, $10 / 24 / 72$. 


\section{Summary}

The State of California Air Resources Board sponsored a major experiment in the chemistry of aerosols in urban and non-urban sites of Californía from 1972 to 1974. The main objectives of this Aerosol Characterization Experiment (ACHEX) were:

1. To characterize aerosols in terms of their physical and chemical properties.

2. To investigate the origins and evolution of aerosols.

3. To estimate the primary and secondary aerosol contributions to the total airborne parttculate concentration in the Los Angeles Basin.

4. To evaluate the significance of anthropogenic sources.

Elemental analysis of intensive and episodic collections of aerosols, together with meteorological data, was the method used to estimate natural and anthropogenic sources of airborne particulates. Wlemental data, combined with other chemical and physical data, also aided the study of secondary aerosol formation. Instrumental neutron activation analysis (INAA) was one of the techniques used to measure elemental diurnal variations and to determine elemental particle glze distributions,
The ACHEX data on the distribution of aerosol composition with size confirm the hypothesis that constituents originating from certain classes of sources dominate the mass in particular size ranges. Primary material from combustion, chemical, and metal refining sources, such as $\mathrm{Br}, \mathrm{Cl}$, and $\mathrm{V}$, appear strongly in the submicron (or anthropogenic) (raction. The natural or quasinatural ele ments such as $\mathrm{Na}, \mathrm{Cj}, \mathrm{Al}, \mathrm{Fe}, \mathrm{Ca}$, and Sc appear in the supermicron fractions. 'n this study the natural background aerosol consisted of a mixture of sea salt, soil dust, and a residue of aged aerosol transported from distances away from an urban area.

A secondary role of INAA was the validation of other analytical techniques utilized in the chemical analysis of aerosols. Supplemental experiments were also performed using INAA to validate the collection efficiencies of rotatir 5 -Btate cascade impactors.

$A s$ a result of these studies, it was concluded that technlques using INAA were useful operational methods for chemical analysis of aerosol samples taken over two-hour periods in urban air in an active monitoring program. 


\section{References}

1. K. Rahn, J. J. Wesolowski, W. John, and H. R. Kalston, "Diurnal Variation of Aerosol Trace Element Concentrations in Livermore, California," J. Air Pollution Control Agsn. 21, 405 (1971).

2. R. Dams, J. A. Robbins, K. A. Rahn, and J. W. Winchester, "Nondestructive Neutron Activation Analysis of Air Pollution Particulates," Analyt. Chem. 42. 861 (1970).

3. W. H. Zoller and G. E. Gordon, "Instrumental Neutron Actlvation Analyais of Atmospheric Pollutants Utilizing Ge(L1) Gamma-Ray Detectors," Analyt. Chem. 42 , 257 (1970).

4. V. P. Guinn, Proceedings of the First International Conference on Forensic Activation Analysis, San Diego, Calif., Sept. 1966, pp. 7-40.

5. H. R. Ralston and G. E. Wilcox, A Computer Method of Peak Area Determinations from Ge-Li Gamma Spectra, Lawrence Livermore Laboratory, Rept. UCRL-71210 (Preprint), (1968).

6. J. J. Wesolowski, S. Wall and S. Twiss, Interlaboratory Comparisons of Chemical Determinations From Aerosols Collected on Cellulose Filters, AJHL Report No, 134 (1973).

7. J. M. Ondov, I. A. Rancitelli, R. H. Fllby, and R. C. Ragaini, "Four Laboratory Comparative Instrumental Nuclear Analysis of the NBS Coal and Fly Ash Standards," 7 th Materiale Regearch Symposium on Accuracy in Trace Analysis, Gaithersburg, Maryland, October 1974.

8. J. M. Ondov, W. H. Zoller, I. Olmez, N. K. Aras, G. E. Gordon, L. A. Rancitelli, K. H. Abel, R, H, Fuby, K. R. Shah, and R. C. Ragaini, "Elemental Cancentrations in the NBS Environmental Coal and Fly Ash Stendard Referenee Materials," Analyt. Chem. 44, 1102 (1975).

9. D. C. Camp, J. A. Cooper, and J. R. Rhodes, "X-Ray Fluorescence Anolysis Results of a First Round Intercomparison Study," X-Ray Spectrometry 3 , ! (1874).

10. R. Glauque, Lawrence Berkeley Laboratory, private communication, January 25 , 1874, May 2, 1974. 